\title{
TEKNIK INTERPRETASI DALAM TAFSIR AL QUR'AN DAN POTENSI DEVIASI PENERAPANNYA MENURUT ILMU DAKHIL
}

\author{
Sihabuddin Afroni, Lc. MA. \\ (Dosen. MK. Agama Islam, Universitas Indobesia) \\ sihabafroni@gmail.com
}

\begin{abstract}
This paper describes the classification of interpretation, especially in terms of methods and techniques of interpretation. The methods and techniques that emerged in this study of the science of interpretation is very diverse and starting point on the tendency and interest of the scholar of the interpreter. Also presented are other factors of the emergence of various methods and styles of interpretation known in the study of the science of Tafsir. Variations and differences of interpretation is a necessity but it does not mean the Qur'an is free of interpretation. A mufassir must be bound by the rules of interpretation proposed by the 'ulama. But sometimes carelessness of the mufassir in accepting secondary texts or other non-selective causes can potentially lead to irregularities and errors in interpretation. Ijtihad they are influenced by the ability of capability, linguistic knowledge, interest in study, text references, flow affiliation, customs, methods and techniques of different interpretations make misinterpretation difficult to avoid. Erroneous interpretation is the object of science research Dakhil. Globally the author introduces in this paper the Dakhil science methodology. Writing this paper using a qualitative method approach that comes from various books relating to the above problems. The author attempts to explain his analysis exposively in order to explain or provide insight into the topics covered.
\end{abstract}

\begin{abstract}
ABSTRAK
Makalah ini memaparkan klasifikasi tafsir terutama dari sisi metode dan teknik interpretasi. Metode dan teknik yang muncul dalam penelitian ilmu tafsir ini sangat beragam dan bertitik tolak pada kecenderungan dan minat keilmuan sang penafsir. Dipaparkan pula faktor-faktor lain dari munculnya beragam metode dan corak tafsir yang dikenal dalam penelitian ilmu Tafsir. Variasi dan perbedaan tafsir adalah suatu keniscayaan namun bukan berarti Al-Qur'an bebas tafsir. Seorang mufassir mesti terikat dengan kaidahkaidah penafsiran yang dikemukakan ulama. Namun terkadang kecerobohan mufassir dalam menerima teks-teks sekunder atau sebab-sebab lain yang tidak selektif itulah yang dapat berpotensi menimbulkan penyimpangan dan kekeliruan dalam penafsiran. Ijtihad mereka dengan dipengaruhi oleh kemampuan daya tangkap, pengetahuan bahasa, minat kajian, referensi teks, afiliasi aliran, adat istiadat, metode dan teknik inetrpretasi yang berbeda menjadikan kekeliruan tafsir sulit untuk dihindari. Kekeliruan Tafsir inilah yang menjadi objek penelitian ilmu Dakhil. Secara global penulis mengenalkan dalam makalah ini metodologi ilmu Dakhil tersebut. Penulisan makalah ini menggunakan pendekatan metode kualitatif yang bersumber dari berbagai buku yang berkaitan dengan permasalahan di atas. Penulis berupaya menjelaskan analisisnya secara eksposisi dengan tujuan untuk menjelaskan atau memberikan pengertian topik yang dibahas.
\end{abstract}

Keywords: Tafseer Classification, Interpretation Method, Interpretation Technique, Technique, Linguistics, Systemic, Socio Historical, Science Dakhil. 


\section{A. Pendahuluan}

Al-Qur'an terjaga dari campur tangan dan unsur asing yang dibuat manusia. Keaslian Al Qur'an ini dijamin sendiri oleh Allah dalam AyatNya. (QS. 6: 115) dan (QS. 15: 9). Jaminan atau garansi keotentikan AlQur'an diberikan Allah Subhanahu wa Ta'ala. atas dasar kemahakuasaan dan kemahatahuan-Nya. Keaslian Al-Qur'an juga berkat upaya-upaya yang dilakukan oleh kaum muslimin. Banyak penghafal Al-Qur'an tersebar di seluruh dunia dengan sendirinya mereka menjadi penjaga keaslian Al-Qur'an. Setiap kejanggalan dan perubahan yang terjadi pasti diketahui oleh penghafal AlQur'an. Dengan berbagai cara umat Islam selalu menjaga keaslian AlQur'an dengan baik, sebab bacaan AlQur'an dijaga dengan kaidah-kaidah pembacaan (qiro'ah) dan terikat dalam aturan ilmu tajwid.

Keterjagaan dan "imunitas" kata dan redaksi Al-Qur'an itu tidak berarti dalam pengertian yang sama bahwa pemahaman dan penafsiran manusia terhadap Al-Qur'an bebas dari kekeliruan dan kesalahpahaman. Menurut Az Zarqani, Tafsir adalah ilmu yang membahas keadaan-keadaan AlQur'an yang mulia dari sisi makna yang terkandung dari maksud Allah sebatas kemampuan manusia. ${ }^{1}$ Tafsir merupakan interpretasi umat Islam terhadap Al-Qur'an dengan berbagai bentuk, metode dan corak. Maka tafsir Al-Qur'an beragam dan bervariasi. Variasi tafsir tersebut merupakan gambaran bahwa Al-Qur'an bagaikan intan yang dapat memancarkan cahayanya ke berbagai sudut kehidupan. Dari pancaran Al-Qur'an tersebut

${ }^{1}$ Muhammad 'Abdul Adzim al Zarqani. 1980. Manahil al-Irfan fi “ulum Al-Qur'an. Kairo: Matba'ah Dar Ihya al Kutub al Arabiyah, Jilid 1, hlm 2 . lahirlah berbagai ilmu keislaman, karena memang Al-Qur'an sendiri mendorong untuk melakukan pengamatan dan penelitian. ${ }^{2}$ Namun variasi tafsir tidak lantas menjadikan semua orang bebas menafsirkan AlQur'an. Penafsiran Al-Qur'an tidak boleh sembarangan, ia sangat terikat dengan kaidah dan metode yang diungkapkan ulama ahli tafsir dari masa ke masa. Penguasaan ilmu alat saja tidak cukup, apabila mufassir tidak memahami metode dan teknik penafsiran. Ketidak tahuan akan metode dan teknik ini akan menyebabkan kekeliruan dalam menafsirkan AlQur'an.

Di kalangan para penggiat tafsir Al-Qur'an, pernyataan bahwa AlQur'an itu bebas tafsir erat kaitannya dengan bahasan at tafsir bir ra'yi (penafsiran Al-Qur'an dengan opini). Karena jika Al-Qur'an dikatakan bebas tafsir artinya semua orang bebas untuk memaknai dan menafsirkan Al-Qur'an dengan opini mereka masing-masing dan pemahaman masing-masing yang keluar dari benak mereka. Apakah benar demikian?

Tafsir meruapakan usaha manusia yang subjektif. Disamping pula AlQur'an, memang merupakan kitab yang yahtamilu wujuhal ma'na (mengandung kemungkinan multi penafsiran). Sehingga adanya pluralitas penafsiran Al-Qur'an adalah wajar-wajar saja, sepanjang dapat dipertanggungjawabkan secara ilmiah dan sesuai kaidah kaidah tafsir yang digariskan oleh para ulama.

Unsur-unsur subjektifitas dalam tafsir adalah suatu keniscayaan. Namun

2 M. Quraish Shihab. 2013. Kaidah Tafsir Syarat, Ketentuan, dan Aturan yang Patut Anda Ketahui dalam Memahami Ayatayat Al-Qur'an. Tangerang: Lentera Hati, hlm. 5. 
bukan berarti Al-Qur'an bebas ditafsirkan oleh manusia. Seorang mufassir dituntut menguasai sejumlah metode dan teknik interpretasi sesuai kaidah tafsir yang dikemukakan oleh ahli ilmu Islam. Seseorang tidak bisa menafsirkan kalamullah jika tidak memiliki kapasitas yang cukup untuk menjadi seorang mufassir. Produk tafisr yang keliru inilah yang dikenal dalam ulumul Qur'an dengan istilah al-Dakhîl fi al-tafsîr. ${ }^{3}$ Kesalahan tafsir tidak terlepas dari kecerobohan mufassir dalam menggunakan berbagai teknik interpretasi penafsiran Al-Qur'an.

Makalah ini akan membahas tentang sejumlah metode dan teknik interpretasi dalam tafsir Al-Qur'an. ${ }^{4}$ Bervariasinya metode dan teknik penafsiran tidak lepas dari perkembangan zaman, keunikan masing masing mufassir dan faktor luasnya kandungan makna Al-Qur'an itu sendiri. Diuraikan pula cara dan teknik yang berkembang dalam penelitian ilmu tafsir. Meski para ulama tafsir telah menetapkan rambu-rambu dalam penafsiran Al-Qur'an, namun tidak menutup kemungkinan seorang mufassir tergelincir dan menyimpang dari kaidah yang telah ditentukan para ulama tersebut. Oleh karena itu makalah ini juga akan memaparkan contoh

\footnotetext{
${ }^{3}$ Al-dakhîl merupakan disiplin ilmu yang mandiri dalam rumpun Ulûm Al-Qurân. Meskipun memang ada pro-kontra apakah Dakhil sebagai sebuah ilmu atau metode, namun ditinjau dari segi kelengkapan sepuluh dasar terbentuknya sebuah ilmu (al mabadi al 'asyroh) materi ini layak disebut dengan ilmu Materi ini secara pokok menkaji kritis sejumlah kekeliruan dan kelemahan dalam penafsiran AlQur'an berdasarkan metodologi/patokan yang telah ditetapkan.

${ }^{4}$ Penulis makalah ini membatasi untuk memfokuskan pada empat teknik interpretasi dalam penafsiran Al-Qur'an. Yaitu; teknik interpretasi tekstual, interpretasi linguistic, interpretasi sistematiis dan interpretasi sosio historis.
}

kesalahan tafsir yang diakibatkan oleh penyimpangan, kecerobohan atau ketidak-konsistenan mufassir dalam menggunaakan teknik interperasi yang benar. Pembicaraan ini akan berangkat pengertian dan perbedaan bentuk, corak, metode dan teknik penafsiran. Jenis dan contoh setiap teknik penafsiran, Sejarah dan faktor-faktor munculnya berbagai bentuk tafsir. Kemudian menguraikan tentang potensi penyimpangan tafsir yang merupakan pembahasan Ilmu Dakhil.

\section{B. Studi Pustaka.}

Banyak orang bingung dan rancu membedakan ketiga istilah "Pendekatan, Metode dan Teknik ". Mengutip pendapat Zamzami Zainuddin, seorang peneliti pendidikan pada Faculty of Education, University of Malaya, Kuala Lumpur bahwa ketiga istilah tersebut memiliki perbedaan ruang lingkup atau cakupan. ${ }^{5} \quad$ Masing-masing istilah mempunyai spektrum dan implementasi sendiri. Secara sederhana list atau penyebutan di atas dibuat secara berurutan mulai dari istilah umum sampai spesifik yaitu: Pendekatan, Metode, dan Teknik.

Menurut Zamzami, yang menguraikan perbedaaan istilah tersebut berangkat dari konteks dunia pengajaran "pendekatan" (approach) memiliki spektrum yang sangat luas dan belum bisa di implementasikan dalam proses belajar mengajar. Karena approach masih asumsi (assumption) dan teori. Sebelum seorang pengajar mengimplementasikan metode pengajarannya, ia harus terlebih dahulu

https://www.kompasiana.com/zamzami.zainudd in/perbedaan-istilah-pendekatan-metode-teknikdan-prosedur-dalampengajaran_56b8ac8bf39273860f425980./dikses tanggal 30 Desember 2017 
mengetahui asumsi, teori dan arah pembelajaran yang akan dibawa saat mengaplikasikan metode nantinya. Kalau dalam istilah politik, approach ini adalah ideologi sedangkan metode adalah partai politik, jadi ideologi dan parpol harus singkron. Satu ideologi juga bisa diadopsi oleh banyak parpol.

Dalam dunia pengajaran kita mengenal sejumlah teori seperrti behaviorism, cognitivism dan constructivis. Penggunaan teori inilah yang disebut dengan approach atau pendekatan. Pengajar harus mengetahui teori apa yang akan ia pakai sebelum menentukan metode belajar-mengajar. Jadi penggunaan teori dalam approach harus selaras dengan penggunaan metode. Misalnya, jika pengajar menggunakan teori constructivism sebagai teori dalam approach, mungkin bisa menggunakan metode communicative karena teori constructivism lebih mengarahkan pada students-center.

Kata "metode" berasal dari bahasa Yunani "methodos" yang berarti cara atau jalan". Di dalam bahasa Inggris kata ini ditulis "method" dan bangsa Arab menerjemahkannya dengan "tharîqah" dan "manhaj". Di dalam bahasa Indonesia kata tersebut mengandung arti: "cara yang teratur dan terpikir, cara kerja yang bersistem untuk memudahkan pelaksanaan suatu kegiatan guna mencapai tujuan yang ditentukan. ${ }^{6}$

Selanjutnya, turunan dari metode adalah teknik yang berarti trik, bagaimana metode dijalankan dalam proses belajar-mengajar. Metode adalah cara umum dan khusus yang dipakai oleh guru dalam proses belajar

6 M. Nashruddin Baidan. 2002. Metode Penafsiran Al-Qur'an Kajian Kritis Terhadap Ayat-Ayat Yang Beredaksi Mirip. Yogyakarta: Pustaka Pelajar, hlm. 54. mengajar. Contoh metode antara lain metode komunikatif dan metode kontekstual. Teknik adalah cara yang dipakai dalam menyelesaikan satu tugas di kelas. Contoh dari teknik adalah teknik permainan, lagu, demonstrasi. Metode lebih luas daripada teknik. Di dalam menggunakan suatu metode guru bisa menerapkan teknik bervariasi. Misalnya, guru menggunakan metode komunikatif dalam pembelajaran Bahasa Inggris. Di dalam kelas ia menggunakan teknik permainan. Dengan kata lain, metode adalah cara untuk mencapai tujuan pembelajaran. Sedangkan cara menyajikan atau memformulasikan tafsir tersebut, dinamakan teknik penafsiran atau seni.

Adapula istilah corak. Corak diistilahkan dalam bahasa Arab yaitu allaun yang arti dasarnya warna. Apabila dikaitkan dengan ilmu tafsir, corak penafsiran yang dimaksud di sini ialah nuansa khusus atau sifat khusus yang memberikan warna tersendiri pada tafsir. ${ }^{7}$ Hal ini terjadi, karena mufassir memiliki latar belakang keilmuan yang berbeda-beda, sehingga tafsir yang dihasilkannya pun memilik corak yang sesuai dengan disiplin ilmu yang dikuasainya.

Dalam klasifikasi tafsir AlQur'an, Quraish Shihab menjelaskan bahwa pada dasarnya tafsir dikelompokkan kepada tiga kelompok utama, yaitu bentuk, metode dan corak tafsir. Dari segi metode muncul tafsir tahlîly/ analisis, tafsir ijmâly global, muqârin/ perbandingan dan maudhû" i/tematik. Sedangkan dari segi bentuknya muncul tafsir bi al-ma"tsûr, tafsir bi ar-ra"y dan tafsir isyâry yang memang sudah sangat popular dalam

7 Abdul Mustaqim. 2005. Aliran-Aliran Tafsir; Dari Periode Klasik hingga Kontemporer. Yogyakarta: Kreasi Warna, hlm. 69. 
kajian tafsir. ${ }^{8}$ Sedangkan terkait corak tafsir beliau mengatakan bahwa corak penafsiran yang dikenal selama ini, antara lain: corak sastra bahasa, corak filsafat, corak teologi, corak penafsiran ilmiah, corak fiqih atau hukum, corak tasawuf, dan corak sastra budaya. ${ }^{9}$

Untuk lebih memudahkan pemahaman, berikut ini penulis tampilkan skema klasifikasi tafsir AlQur'an: ${ }^{10}$

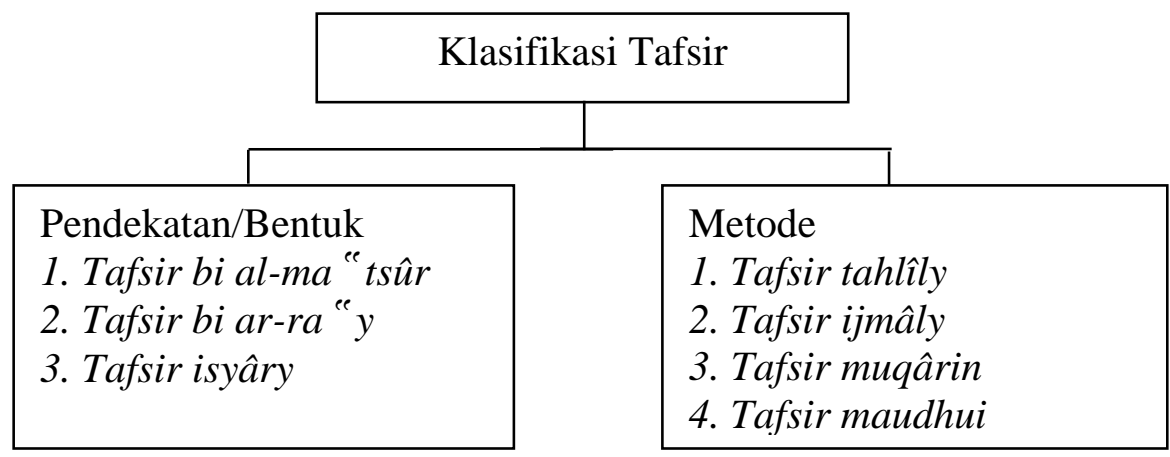

Corak

1. Tafsir Bahasa

2. Tafsir Filasafat

3. Tafsir Teologi

4. Tafsir Fiqih

5. Tafsir Tasawuf dll.
Teknik

1. Interpretasi Tekstual

2. Interpretasi Linguistik

3. Interpretasi Sistemis

4. Interpretasi Sosio Historis

5. Interpretasi Sosiologis

6. Interpretasi Kultural hlm. 349.

${ }^{8}$ M. Quraish Shihab. Kaidah Tafsir...,

${ }^{9}$ M. Quraish Shihab. 1992. Membumikan al-Qur'an. Bandung: Mizan. hlm. 72

10 Azkia Muharom Albantani. 2016. Pendekatan Dalam Tafsir: Tafsir bi al-Ma'tsûr, Tafsir bi al-Ra'yi, dan Tafsir bi al-Isyârah. Jurnal Hikamuna, Vol 1, No. 2, 2016, hlm. 31. 


\section{Metode Pembahasan.}

Penelitian ini mengambil metode Library Research (penelitian kepustakaan), dimana bahan penelitian diambil dari sumber-sumber refrensi ilmu ushūl tafsìr, metodologi tafsir dan buku-buku yang berkaitan dengan ilmu dasar tafsir.

Karena objek penelitian ini adalah tentang penerapannya ilmu dakhil dalam teknik interpretasi dalam tafsir al qur'an maka teknik analisis data yang digunakan adalah pendekatan analisis historis yang memiliki ciri (1) lebih banyak menggantungkan diri pada data yang diamati orang lain di masa-masa lampau; (2) lebih banyak bergantung kepada data primer dibandingkan dengan data sekunder, sehingga bobot datanya harus dikritik, baik secara internal ataupun eksternal; (3) mencari data secara lebih tuntas, serta menggali informasi yang lebih tua yang tidak diterbitkan ataupun yang tidak dikutip dalam bahan acuan yang standar; dan (4) sumber data harus dinyatakan secara definitive, baik nama pengarang, tempat dan waktu, untuk kemudian diuji kebenaran dan keasliannya. ${ }^{11}$

\section{Hasil Pembahasan.}

Pada masa awal Islam, tidak ditemukan ulama salaf yang membahas tentang metodologi tafsir secara khusus. Karena, pada saat itu mereka belum merasa perlu menetapkan kajian khusus mengenai metodologi tafsir. Uumumnya mereka menguasai ilmu-ilmu yang diperlukan dalam menafsirkan AlQur'an, seperti ilmu bahasa Arab, balagah, sastra, dan sebagainya. Akan tetapi, bukan berarti mereka menafsirkan Al-Qur'an tanpa metode, sebaliknya metode yang diterapkan oleh

11 Nazir, Moh. 2003. "Metode Penelitan”. Jakarta: Ghalia Indonesia. hlm. 93. generasi pertama itulah yang dikembangkan oleh para mufassir yang datang kemudian. Metode tafsir yang pertama kali muncul saat itu adalah metode Ijmali (global), yang mengambil bentuk dalam tafsir bi al-ma'sur, kemudian nantinya diikuti oleh bentuk al-ra'yi seperti dalam tafsir alJalalain. $^{12}$

Metode Ijmali inilah yang kemudian berkembang terus hingga melahirkan apa yang disebut metode analitis (tahlili), yang ditandai dengan munculnya kitab-kitab tafsir yang yang memberikan uraian cukup luas dan mendalam tentang pemahaman suatu ayat, seperti tafsir al-Tabari dalam bentuk al-ma'sur, dan tafsir al-Razi dalam bentuk al-ra'yi. Seiring perkembangan zaman, para ulama tafsir berusaha menafsirkan Al-Qur'an lebih pesifik lagi, lalu mereka mengkhususkan tafsirannya pada bidang-bidang tertentu, maka lahirlah tafsir fiqh, tasawuf, teologi, bahasa, dan sebagainya. Itulah yang kemudian diistilahkan dengan corak tafsir. Pada periode selanjutnya, sekitar abad ke-5 Hijriyah, lahir pula metode komparatif (muqarin). Dalam bidang ini, tercatat kitab Durrat al-Tanzil wa Gurrat alTa'wil oleh al-Khatib al-Iskafi, dan alBurhan fi Tawjih Mutasayabih AlQur'an oleh Taj Al-Qur'an' alKarmani. Di sisi lain, munculnya berbagai corak tafsir, mengilhami para ulama tafsir untuk menyusun metode baru dalam penafsiran Al-Qur'an, hingga melahirkan metode tematik (maudu'i).

Meskipun pola penafsiran tematik ini secara embriotik telah lama dikenal dalam sejarah tafsir, namun dalam bentuknya yang dikenal sekarang, pertama kali ditulis Prof. Dr. Ahmad alKumi (Ketua Jurusan Tafsir pada

12 M. Nasharuddin Baidan. Metode Penafsiran Al-Qur'an. hlm. 53. 
Fakultas Ushuluddin, Universitas alAzhar). Kalau pendapat ini diterima, maka metode tematik dikatakan baru lahir secara faktual pada paruh kedua abad ke-20 yang lalu. ${ }^{13}$ Quraish Shihab menjelaskan bahwa metode yang dicetuskan oleh al-Kumi ini merupakan kelanjutan dari metode tematik gaya Mahmud Syaltut, dalam tafsirnya Tafsir Al-Qur'an al-Karim, yang disusun pada bulan Januari 1960, sedangkan al-Kumi mencetuskan ide itu pada akhir tahun enam puluhan. ${ }^{14}$

Di antara keempat metode tersebut, yang paling populer adalah metode tahlili dan maudu'i. Keunggulan dari metode tahlili adalah pembahasannya yang luas, karena ayat Al-Qur'an dianalisis dari berbagi segi, mulai dari kosakata, sebab turunnya ayat, munasabah, dan hal-hal lain yang berkaitan dengan teks atau kandungan ayat. Namun, meskipun metode ini dinilai sangat luas, namun tidak menyelesaikan satu pokok bahasan, karena seringkali satu pokok bahasan diuraikan kelanjutannya pada ayat lain, sehingga metode ini tidak mampu memberi jawaban tuntas terhadap persoalan-persoalan yang dihadapi sekaligus, karena sifat penafsirannya amat teoretis dan tidak sepenuhnya mengacu kepada persoalan-persoalan khusus yang mereka alami dalam masyarakat. $^{15}$

Adapun faktor-faktor ayang menyebabkan munculnya variasi bentuk, metode dan teknik penafsiran

13 M. Nasharuddin Baidan. Metode Penafsiran Al-Qur'an. hlm. 54.

${ }^{14}$ M. Quraish Shihab. Membumikan AlQur'an. hlm. 76.

${ }^{15}$ M. Quraish Shihab. Membumikan AlQur'an. hlm. 86-87.
Al-Qur'an dapat diuraikan sebagai berikut:

1. Luasnya Makna Al-Qur'an Merupakan Aspek kemukjizatan AlQur'an

Tafsir adalah satu bentuk hasil kajian yang mendalam terhadap AlQur'an. Jumlah kitab tafsir saat ini sudah sangat banyak, namun seorang pengkaji Al-Qur'an tidak akan kehabisan mutiara yang terdapat di dalam Al-Qur'an. Dari satu AlQur'an yang sama, lahirlah ribuan karya, termasuk karya tafsir dengan berbagai corak dan metodenya. Semakin dikaji, maka akan semakin banyak pengetahuan yang didapatkannya. Hal ini tersurat dengan jelas pada QS. AlKahfi/18:109

$$
\begin{aligned}
& \text { قُلن لَوْ كَانَ الْبَحْرُ مِدَادًا }
\end{aligned}
$$

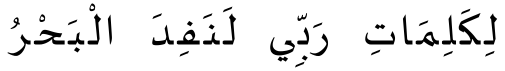

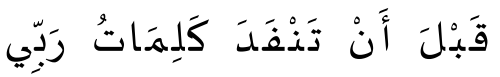

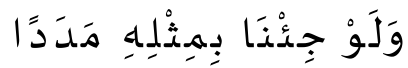

$$
\begin{aligned}
& \text { "Katakanlah: Sekiranya } \\
& \text { lautan menjadi tinta untuk } \\
& \text { (menulis) kalimat-kalimat } \\
& \text { Tuhanku, sungguh habislah } \\
& \text { lautan itu sebelum habis } \\
& \text { (ditulis) kalimat-kalimat } \\
& \text { Tuhanku, meskipun Kami } \\
& \text { datangkan tambahan } \\
& \text { sebanyak itu (pula)". }
\end{aligned}
$$

2. Perintah Allah S.W.T. untuk senantiasa tadabbur (merenungkan) makna Al-Qur'an.

Terdapat banyak ayat yang berisi perintah untuk merenungkan makna yang terkandung dalam AlQur'an. Setiap orang memiliki kebebasan untuk hal tersebut. Di sisi lain, setiap orang memiliki tingkat kecerdasan yang berbeda, atau bahkan disiplin ilmu yang berbeda. 
Hal ini berimplikasi pada perbedaan hasil perenungannya terhadap AlQur'an. Quraish Shihab menuliskan bahwa perbedaan adalah konsekuensi logis dari perintah tadabbur Al-Qur'an, selama pemahaman dan penafsiran tersebut dilakukan secara sadar dan penuh tanggung jawab. ${ }^{16}$ Yang dimaksud dengan kebebasan yang bertanggung jawab dalam hal ini adalah adanya pembatasan-pembatasan berupa syarat-syarat diterimanya sebuah tafsir Al-Qur'an, sebagaimana pembatasan-pembatasan yang dikemukakan dalam setiap disiplin ilmu. ${ }^{17}$ Oleh karena itu, setiap orang bisa memetik hikmah dari setiap kegiatan pembacaannya terhadap AlQur'an, namun ia tidak dapat memaksakan pemahamannya untuk diakui sebagai penafsiran, kecuali memenuhi standar kualifikasi tafsir yang sudah ditentukan oleh para ulama.

3. Keuniversalan Al-Qur'an yang diperhadapkan pada zaman yang senantiasa bekembang.

Al-Qur'an sahih li kulli zaman wa makan, sehingga menuntut adanya fleksibilitas dalam memahami Al-Qur'an, mengingat problematika kehidupan senantiasa berkembang. Oleh karena itu, yang perlu diubah bukanlah teks AlQur'an, melainkan bagaimana rekonstruksi terhadap pemahaman Al-Qur'an itu dilakukan. Dan hal tersebut dapat tercapai dengan adanya pembaharuan metodologi tafsir, sebagaimana diungkapkan oleh Munzir Hitami, dalam buku

${ }^{16}$ M. Quraish Shihab. Membumikan AlQur'an. hlm. 76.

${ }^{17}$ M. Quraish Shihab. Membumikan AlQur'an. hlm. 85.
Pengantar Studi Al-Qur'an: Teori dan Pendekatan. ${ }^{18}$

4. Spesialisasi ilmu pengetahuan

Semakin hari, ilmu pengetahuan semakin berkembang. Salah satu bukti nyata dari perkembangan tersebut adalah dengan spesialisasi ilmu pengetahuan. Spesialisasi dimaksudkan agar seseorang lebih fokus dalam mendalami sebuah ilmu. Disiplin ilmu yang berbeda-beda inilah yang kemudian berpengaruh besar pada muncul corak tafsir yang bervariasi.

Seperti contoh, yang ahli nahwu melakukan penafsiran dari sudut pandang nahwu, seperti al-Zujaj, alWahidi, dan Abu Hayyan. Yang ahli teologi melakukannya dari sudut pandang teologi, seperti al-Razi dalam Mafatih al-Gaib. Yang bergelut di dunia sufi menafsirkan Al-Qur'an dengan pendekatan sufistik, seperti Ibnu 'Arabi dan 'Abd al-Razzaq al-Kasyani, dan sebagainya. ${ }^{19}$

5. Kebutuhan akan metode tafsir yang dapat menjawab persoalan-persoalan masyarakat secara tuntas.

Metode tematik menjadi metode yang paling populer digunakan, karena metode-metode tafsir yang ada sebelumnya belum mampu memberikan sebuah pemahaman yang komprehensif terhadap ayatayat Al-Qur'an. ${ }^{20}$ Oleh karena itu, boleh jadi di masa yang akan datang akan muncul metode baru dalam menafsirkan Al-Qur'an, namun

${ }^{18}$ Munzir Hitami. 2012. Pengantar Studi Al-Qur'an: Teori dan Pendekatan. Cet. I; Yogyakarta: LKiS, hlm. 113.

19 Muhammad Husain al-Tabataba'i. 1998. Al-Qur'an fi al-Islam (Mengungkap Rahasia Al-Qur'an. terj. A. Malik Madaniy, dkk. Cet. XI; Bandung: Mizan, hlm. 67.

${ }^{20}$ M. Quraish Shihab. Membumikan AlQur'an. hlm. 74. 
tentunya metode tersebut tidak dapat terlepas begitu saja dari keempat metode yang telah ada.

\section{D.1. Teknik Interpretasi dalam Penafsiran Al Quran}

Kata "teknik" dalam Kamus Besar Bahasa Indonesia berarti cara sistematis mengerjakan sesuatu. ${ }^{21}$ Adapun kata "interpretasi", yang disadur dari bahasa Inggris interpretation, berarti pemberian kesan, pendapat, atau pandangan teoritis terhadap sesuatu; tafsiran. ${ }^{22}$

Dalam metodologi penelitian ilmu Tafsir terdapat banyak teknik interpretasi dalam penafsiran Al-Qur'an yaitu; Interpretasi Tekstual, Interpretasi Linguistik, Interpretasi Sistematis, Interpretasi Sosio Historis, Interpretasi Teologis, Interpretasi Kultural, Interpretasi Logis. Namun dalam makalah ini akan dibahas empat teknik interpretasi saja.

\section{D.1.a. Interpretasi Tekstual}

Kata "tekstual" berasal dari Bahasa Inggris textual yang berarti relating to a written text, especialy literacy texts (berkenaan dengan teks tertulis; khususnya berdasarkan teks atau naskah). ${ }^{23}$ Teks berarti naskah yang berupa kata-kata asli dari pengarang atau kutipan dari kitab suci untuk pangkal ajaran atau alasan atau bahan tertulis untuk dasar memberikan

${ }^{21}$ Pusat Bahasa Departemen Pendidikan dan Kebudayaan. 1996. Kamus Besar Bahasa Indonesia. edisi II Cet. VII; Jakarta: Balai Pustaka, hlm. 1024.

${ }^{22}$ Pusat Bahsa Departemen Pendidikan dan Kebudayaan. Kamus Besar Bahasa Indonesia. hlm. 384.

https://www.collinsdictionary.com/dictionary/en glish/textual/diakses /tanggal 1 Januari 2017. pelarajan, berpidato dan lain sebagainya. $^{24}$

Secara istilah interpretasi tekstual dapat diartikan sebagai kecenderungan atau metode penafsiran yang menitikberatkan pada makna teks secara harfiah (literal) dengan tanpa menyertakan konteks sosio-historis teks dalam aktivitas penafsirannya: di mana, kapan, dan mengapa teks tersebut lahir, dan bagaimana proyeksi makna teks ke depan. Karena, mengedapankan makna harfiah teks di satu sisi, dan menafikan peran keterlibatan sang penafsir di sisi lain, maka penetapan maknanya menjadi dominan otoritas teks. Di luar teks tidak ada makna yang bisa dipertanggungjawabkan dan diyakini maknanya. $^{25}$

Biasanya kata tekstual diungkapkan untuk membedakan kata 'kontekstual'. Konteks sendiri berarti kondisi di mana suatu keadaan terjadi. Ada beberapa jenis konteks. Konteks fisik meliputi ruangan, objek nyata, pemandangan, dan lain sebagainya. Bagian suatu uraian atau kalimat yang dapat mendukung atau menambah kejelasan makna; hari dan rentetan peristiwa yang dirasakan terjadi sebelum peristiwa komunikasi. ${ }^{26}$

Teknik interpretasi tekstual yang pada umumnya dipahami adalah memahami teks seperti "apa adanya teks", dipahami sesuai dengan yang tersurat. Ketika teks Al-Qur'an menjelaskan dirinya sendiri tanpa harus memperhatikan unsur yang

\footnotetext{
${ }^{24}$ Pusat Bahasa Departemen Pendidikan dan Kebudayaan. Kamus Besar Bahasa Indonesia. hlm. 1474.

25 H. U. Syafrudin. 2009. Paradigma Tafsir Tekstual dan Kontekstual. Cet. 1;

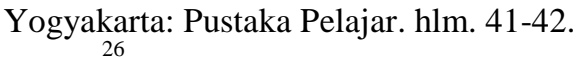

https://id.wikipedia.org/wiki/Konteks/diakses 1 Januari 2017
} 
melingkupinya, maka teks tersebut dipahami tekstual. Muin Salim seperti dikutip oleh Muh. Zuhri Abu Nuwas lebih memahami tekstual dengan penafsiran teks dengan teks, baik teks Al-Qur'an maupun teks hadis, atau lebih dikenal dengan tafsir bi alma'tsur. Teknik interpretasi tekstual adalah menafsirkan teks-teks Al-Qur'an dengan menggunakan teks-teks AlQur'an sendiri ataupun dengan hadis Nabi saw. Dasar penggunaan teknik ini, menurutnya, adalah penegasan AlQur'an bahwa ia berfungsi sebagai penjelasan terhadap dirinya sendiri dan tegas Nabi sebagai mubayyin terhadap Al-Qur'an. ${ }^{27}$

Oleh karena itu teknik interpretasi tekstual terbagi menjadi dua bagian yaitu interpretasi dengan Al-Qur'an, tentu sumbernya adalah Allah S.W.T. sebagai pemilik teks, sementara yang kedua adalah dengan hadis, dan sumbernya adalah Nabi Shalallahu'alaihi wa Sallam. sebagai mubayyin terhadap teks (Al-Qur'an). Muhammad 'Ali as-Sabuni dalam Tibyan fi 'Ulum Al-Qur'an menambahkan dengan qaul sahabah. Tafsir jenis ini Ali as-Sabuni menyebutnya sebagai langkah penafsiran dan memasukkannya sebagai turunan dari jenis tafsir bil ma'sur. Hal ini karena ia membagi tafsir ke dalam tiga bagian yaitu tafsir bi riwayah, dirayah, dan isyarah.

Nabi Muhammad Shalallahu'alaihi wa Sallam. dipandang sebagai mubayyin (yang menjelaskan) Al-Qur'an. Dengan begitu maka orang yang pertama yang mendapatkan otoritas untuk menginterpretasikan AlQur'an adalah Nabi Muhammad

27 Muh. Zuhri Abu Nawas. 2015. “Teknik Interpretasi Tekstual Dan Kontekstual". Jurnal Al Asas, IAIN Palopo, Vol. III, No. 1, April. hlm 101.
Shalallahu'alaihi wa Sallam. interpretasi tekstual dipandang lebih akurat dalam menghasilkan konsep dibandingkan dengan natijah (produk) itu sendiri. Hal ini merupakan faktor pertama untuk menghasilkan derajat "interpretasi utama". Hal ini dipandang lebih menjaga dan menjauhkan mufasir dari kesalahan interpretasi yang disebabkan oleh adanya pergeseran makna bahasa yang terjadi dalam proses perkembangan bahasa. ${ }^{28}$

Pada pembahasan ini tafsir tekstual dibagi menjadi dua yaitu interpretasi Al-Qur'an dengan AlQur'an dan tafsir Al-Qur'an dengan Sunnah:

\section{Interpretasi Dengan Teks Al- Qur'an}

Secara eksplisit Al-Qur'an menyatakan bahwa kewenangan memberikan bayan (penjelasan) terhadap ayat-ayat Al-Qur'an adalah otoritas Allah dan Rasulnya. Meskipun demikian tidak berarti bahwa ayat-ayat Al-Qur' an tidak boleh lagi digali makna dan kandungannya karena Al-Qur'an adalah kitab hidayah yang senantiasa terbuka dikaji oleh siapapun termasuk mereka yang tidak mempercayainya sebagai kitab suci yang diwahyukan Allah kepada Muhammad Shalallahu'alaihi wa Sallam. Qur'an

a. Model Interpretasi dengan AlMenurut ulama model penafsiran qurani ini terbagi menjadi dua macam yaitu tafsir muttasil dan tafsir munfasil. ${ }^{29}$ Tafsir muttasil ini maksudnya ialah ayat yang menafsirkan bersambung dengan ayat yang

${ }^{28}$ Abd Muin Salim, dkk. 1433 H/ 2011 M. Metodologi Penelitian Tafsir Maudhu'i. Makassar; Pustaka al-Zikra. hlm. 130

${ }^{29}$ Abd Muin Salim, dkk. Metodologi Penelitian Tafsir Maudhu'i. hlm. 135. 
ditafsirkan seperti dalam QS. AlTariq/86: 2-3

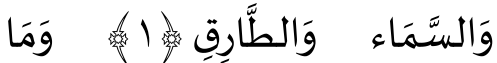

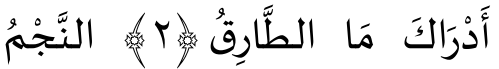

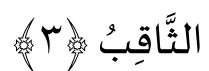

"Demi langit dan yang datang pada malam hari, (1) Tahukah kamu apakah yang datang pada malam hari itu? (2) (yaitu) bintang yang cahayanya menembus". (3)

Pada ayat di atas terdapat pertanyaan yang maknanya menafikan kemampuan memahami apa yang dimaksud dengan al-tariq sedangkan pada ayat ketiga menegaskan bahwa yang dimaksud al-tariq itu ialah bintang yang cahanya menembus. ${ }^{30}$

Kemudian tafsir munfasil yaitu kedua ayat terkait tapi tidak bersambung seperti halnya bentuk pertama. Walaupun kedua ayat atau tidak bersambung namun, diantara mereka terdapat titik temu sehingga ayat-ayat itu dapat dipandang memiliki hubungan penjelasan. Salah satu contoh tafsir munfasil ini sebagaimana dalam QS. Al-An'am/6: 82.

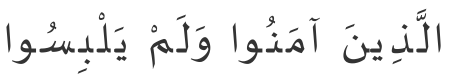

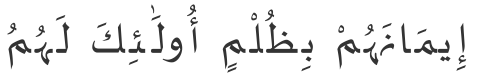

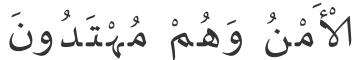

"Orang-orang yang beriman dan tidak mencampuradukkan iman mereka dengan kezaliman (syirik), mereka itulah yang mendapat keamanan dan mereka itu adalah orang-

30 Abdurrahman ibn Abi Bakr Jalal alDin al-Suyuti. al-Dur al-Mansiur. Juz. VIII Bairut; Dar al-Fikr, t.th. hlm. 747. orang yang mendapat
petunjuk".

Pada ayat di atas dijelaskan oleh Rasulullah sendiri dalam sebuah riwayat yang diriwayatkan oleh AlBukhari

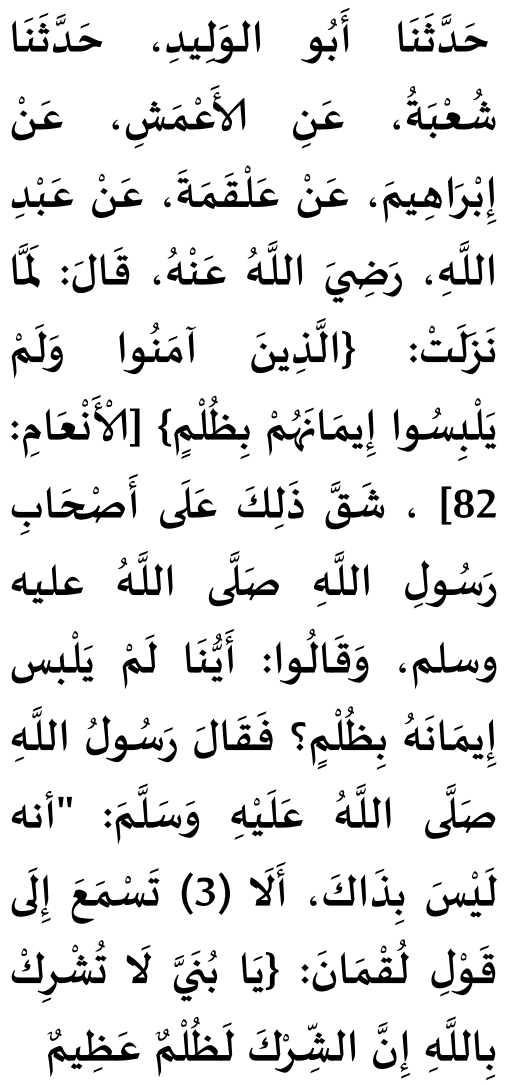

"Telah menceritakan kepada kami Abu Al Walid berkata, telah menceritakan kepada kami Syu'bah dari A'masy dari Ibrahim dari Alqamah dari Abdullah berkata: ketika turun ayat: "Orangorang beriman dan tidak mencampur adukkan iman mereka dengan kezhaliman" para sahabat Rasulullah shallallahu 'alaihi wasallam bertanya: "Siapakah diantara kami yang tidak berbuat zhalim? Maka Allah 'Azza wajalla menurunkan (firman-Nya):

"Sesungguhnya kesyirikan 
adalah kezhaliman yang besar". (QS. Luqman: 13) (HR. Bukhari) $^{31}$

\section{Interpretasi Al-Quran dengan}

\section{Teks Hadits Nabi.}

Tafsir yang diberikan oleh Rasulullah bersumber dari wahyu. Sebagaimana tafsian pada QS. AlNajam/53: 2-3

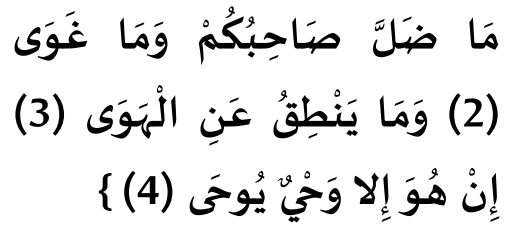

"Kawanmu (Muhammad) tid ak sesat dan tidak pula keliru, dan tiadalah yang diucapkannya itu (AlQur'an) menurut kemauan hawa nafsunya. Ucapannya itu tiada lain hanyalah wahyu yang diwahyukan (kepadanya).

Menurut Al-Farra' bahwa apa yang dikatakan oleh Rasulullah dengan ra'yu-nya terhadap Al-Qur'an bahwa itu adalah wahyu. ${ }^{32}$ Interpretasi dengan Sunnah menjadi dua bagian yaitu dari pernyataan Nabi baik itu dari praktis (amali) atau statemen (qauli) dari pernyataan sahabat. Nabi menjelaskan apa makna suatu ayat terntentu. Sementara tafsir praktis bisa disebut tafsir langsung. Sebagian besar tafsir Nabi untuk para pengikutnya adalah tafsir praktis ketimbang ekspositoris. Orang-orang disekeliling Nabi memahami bahasa Arab Al-Qur'an

\footnotetext{
${ }^{31}$ http://library.islamweb.net/newlibrary/d isplay_book.php?idfrom $=8646 \&$ idto $=8651 \&$ bk _no $=52 \& I D=2550 /$ diakses 1 Januari 2018

32 Abu Zakariyya Yahya ibn Ziyad ibn 'Abdullah ibn Manzur al-Dailami al-Farra'. Ma'ani Al-Qur'an. Juz. III Cet. I; Mesir: Dar alMisriyyah, t.th. hlm. 95.
}

yang sederhana dan karenanya menjelaskan masing-masing kata, frase, atau kalimat. ${ }^{33}$

Salah satu contoh tafsir Nabi qauli pada QS. Al-Anfal/8: 60.

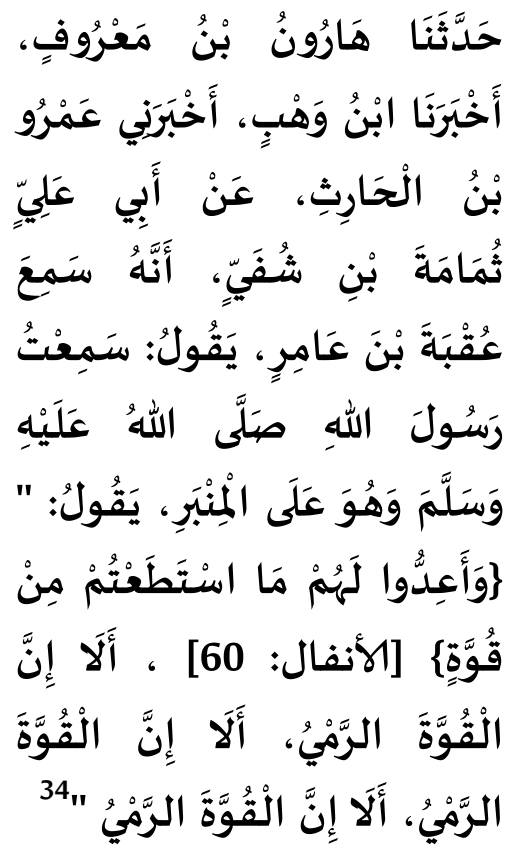

...Saya mendengar
Rasulullah bersabda diatsa
mimbar belaiu membaca
suatu ayat yaitu siapkanlah
untuk menghadapi mereka
(musuh) apa yang mampu
kamu siapkan dari kekuatan.
Ingatlah bahwa kekuatan
yang dimaksud ialah
memanah beliau
mengulanginya tiga kali.

33 Abdullah Saeed. 2016. Interpreting The Qur'an: Towards a Contemporary Approach. diterj. Lien Iffah Naf'atu Fina, Paradigma, Prinsip dan Metode Penafsiran Kontekstualis Al-Qur'an. Cet. II; Yogyakarta: Baitul Hikmah Press. hlm. 89-90.

${ }^{34}$ Muslim ibn Hajjaj Abu al-Hasan alQusyairiy al-Naisaburiy. al-Musnad al-Sahih alMukhtasar bi Naql al-'Adl ila Rasulillah. Bairut; Dar Fu'ad 'Abd al-Baqiy, t.th, Juz III, hlm 1522. 


\section{D.1.b. Interpretasi Linguistik}

Teknik penafsiran lain yang sangat signifikan dalam memahami AlQur'an adalah pendekatan linguistik atau yang lebih dikenal dengan istilah tafsir lughawi. Tafsir lughawi sangat diperlukan dalam memahami Al-Qur'an di samping karena Al-Qur'an menggunakan bahasa arab yang penuh dengan sastra, balaghah, fashahah, bayan, tamsil dan retorika, Al-Qur'an juga diturunkan pada masa kejayaan syair dan linguistik. Bahkan pada awal Islam, sebagian orang masuk Islam hanya karena kekaguman linguistik dan kefasihan al-Qur'an. ${ }^{35}$ Yang dimaksud dengan tafsir lughawi adalah tafsir yang mencoba menjelaskan makna-makna Al-Qur'an dengan menggunakan kaidah-kaidah kebahasaan. atau lebih simpelnya tafsir lughawi adalah menjelaskan Al-Qur'an al-Karim melalui interpretasi semiotik dan semantik yang meliputi etimologis, morfologis, leksikal, gramatikal dan retorikal. $^{36}$

Ketika seseorang ingin menafsirkan Al-Qur'an dengan pendekatan bahasa harus mengetahui bahasa yang digunakan Al-Qur'an yaitu bahasa Arab dengan segala selukbeluknya, baik yang terkait dengan Nahwu, Balaghah dan Sastranya. Dengan mengetahui bahasa Al-Qur'an, seorang mufassir akan mudah untuk melacak dan mengetahui makna dan susunan kalimat-kalimat Al-Qur'an sehingga akan mampu mengungkap makna di balik kalimat tersebut. Bahkan

${ }^{35}$ Salah satu contohnya adalah Umar bin Khattab yang kagum terhadap Al-Qur'an ketika dia mendengar Rasulullah membaca surah alHaqqah. untuk lebih lengkapnya baca, Shafiyyurrahman al-Mubarakfury. 1994. alRahiq al-Makhtum. Riyad: Maktabah Dar alSalam. hal. 101

${ }^{36}$ Abd Muin Salim. Metodologi Tafsir. hlm. 34
Ahmad Syurbasyi menempatkan ilmu bahasa dan yang terkait (nahwu, sharaf, etimologi, balaghah dan qira'at) sebagai syarat utama bagi seorang mufassir. ${ }^{37}$ Di sinilah, urgensi bahasa akan sangat tampak dalam penafsirkan Al-Qur'an. Orang pertama yang memahami dan menafsirkan Al-Qur'an adalah Rasulullah, di samping karena ada perintah Allah untuk menjelaskan wahyu tersebut. (QS; An-Nahl: 44) Salah satu cara Rasulullah menjelaskan dan menafsirkan Al-Qur'an adalah melalui pendekatan bahasa dengan mencarikan makna muradif (sinonimnya) atau menjelaskan makna kosa kata dalam ayat-ayat Al-Qur'an. ${ }^{38}$

Setelah Rasulullah, orang yang paling memperhatikan, mempelajari, menghafal dan merealisasikan AlQur'an adalah para sahabat. Akan tetapi sebelum mengamalkan Al-Qur'an, mereka meancari tahu tentang makna setiap lafal atau kata yang tidak termasuk dalam bahasa mereka, atau kata yang jarang digunakan atau kata yang tidak menggunakan makna aslinya. Dan hal itu marak terjadi setelah Rasulullah telah tiada. Sahabat yang paling banyak ditanya tentang makna dan sinonim kalimat Al-Qur'an dan paling banyak menafsirkan AlQur'an melalui pendekatan bahasa atau syair-syair arab klasik adalah Abdullah bin Abbas. ${ }^{39}$

Penafsiran Abdullah bin Abbas yang cenderung menjadikan syair sebagai salah satu sumber penafsirannya merupakan cikal bakal munculnya madrasah lughah. Hal itu terjadi ketika

37 Ahmad Syurbasyi. 1999. Sejarah Perkembangan Tafsir Al-Qur'an al-Karim. Jakarta: Kalam Mulia, Cet. I, hlm. 31.

38 Musthafa al-Shawi al-Juwaini. Manahij fi al-Tafsir. Iskandariyah: Mansya'ah al-Ma'arif. hlm. 16.

${ }^{39}$ Musthafa al-Shawi al-Juwaini. Manahij fi al-Tafsir. hlm. 23. 
menjadi pengajar dan pembimbing di madrasah tafsir di Makkah yaitu pada abad pertama Hijriyah dan diteruskan oleh para murid-muridnya seperti Said bin Jabir, Mujahid bin Jabar, Ikrimah, Thawus bin Kaisan dan Atha' bin Abi Rabah hingga abad ke-2 Hijriyah. ${ }^{40}$

Analisis Penafsiran dan pemikiran terhadap Al-Qur'an tidak akan bisa dilakukan tanpa bahasa karena bahasalah yang mengantarkan dan menghubungkan antara kandungan makna lafal dengan lafal yang lain. Tanpa bahasa, analisis pemikiran tidak akan berarti apa-apa. Oleh karena itu, peran dan pengaruh dari tafsr lughawi tentu akan mencakup sekian banyak aspek atau corak penafsiran. Di antaranya:

1. Aspek hukum (fiqh) seperti ketika menafsirkan kalimat وأرجلكم dalam masalah wudhu' surah al-Maidah ayat 6 , jika dibaca manshub (harkat fathah) maka yang wajib dilakukan pada kaki ketika berwudhu' adalah membasuh bukan mengusap, tetapi jika majrur (harkat kasrah) maka yang wajib hanya mengusap. ${ }^{41}$ Masih banyak contoh-contoh yang lain.

2. Aspek teologi seperti pada saat menafsirkan إياك نعبد وإياك نستعين dengan didahulukannya lafal إياك dari lafal نعبد, berarti dalam beribadah tidak boleh terjadi kesyirikan karena lafal tersebut bermakna hashar (terbatas, khusus).

3. Aspek filsafat misalnya ketika menafsirkan lafal شياطين الجن dalam

40 Musthafa al-Shawi al-Juwaini. Manahij fi al-Tafsir. hlm. 77.

${ }^{41}$ Abu Abdillah al-Qurthubi. 2003. AlJami' li Ahkam Al-Qur'an. Bairut Lebanon: Dar al-Kutub al-Araby, Cet. V, Jilid. 6 hlm. 90. surah al-An'am ayat 112 dengan melakukan pendekatan makna akar جنن kata dari kata شطن dan) dauh (yang tersembunyi) maka sekelompok filosof menafsirkan lafal tersebut dengan "Nafsu yang jauh berpisah lagi jelek yang berlindung dari panca indra". 42

4. Aspek sufistik semisal ketika Ibnu عند ومن عن zوبه يظظ dalam surah al-Hajj ayat 30, sehingga maksud ayat ini bisa mengarah kepada ajaran tasawwuf yaitu "Barang siapa yang mengagungkan kemulyaan Allah di sisi Tuhannya pada suatu tempat, maka hendaklah dia cari pada tempat yang lain yang ada di sisi Tuhanmu.

5. Aspek ilmy (saintifik) yaitu ketika menafsirkan lafal سلطان dalam surah al-Rahman ayat 33, sebagian pakar mengatakan bahwa seseorang mampu mencapai luar angkasa dengan سلطان. Begitu juga saat menafsirkan surah al-Furqan ayat 53 yang menunjukkan adanya pemisah antara air tawar dan asin melalui pendekatan bahasa. ${ }^{43}$

Tafsir lughawi dengan berbagai macam penyajian dan pembahasannya tidak akan keluar dari dua kelompok besar yaitu:

1. Tafsir lughawi yang murni atau lebih banyak membahas hal-hal yang terkait dengan aspek bahasa saja, seperti tafsir Ma'an Al-Qur'an karya al-Farra', Tafsir al-Jalalain karya

42 Muhammad Husain az-Zahabi. AlTafsir wa Al-Mufassirun. hlm 143.

${ }^{43}$ M. Quraish Shihab. 2006. Mukjizat AlQur'an. Bandung: Mizan Pustaka, Cet. XVI, hlm. 175-180. 
Al-Suyuthi dan Al-Mahally. Dan lain-lain.

2. Tafsir lughawi yang pembahasannya campur-baur dengan pembahasan lain seperti hukum, theology dan sejenisnya, seperti Tafsir al-Thabary li Ibn Jarir al-Thabary, Mafatih alGhaib li al-Fakhruddin Al-Razy, dan sebagian besar tafsir dari awal hingga sekarang, termasuk Tafsir alMishbah yang disusun oleh Quraish Shihab. ${ }^{44}$

\section{D.1.c. Interpretasi Sistemis}

Dalam Kamus Besar Bahasa Indonesia kata sistemis diartikan dengan bertalian atau berhubungan dengan suatu sistem atau susunan yang teratur. ${ }^{45}$ Dalam ilmu hukum, penafsiran sistemis adalah suatu penafsiran yang menghubungkan pasal yang satu dengan pasal-pasal yang lain dalam suatu perundang-undangan yang bersangkutan atau pada perundang-undangan hukum lainnya, sehingga kita mengerti apa yang di maksud. ${ }^{46}$

Dalam ilmu Tafsir teknik interpretasi sistemis adalah cara menyajikan pngambilan makna atau interpretasi suatu ayat dikaitkan dengan ayat-ayat lain yang berkorelasi di dalam maupun di luar surahnya. ${ }^{47}$ Tegasnya di sini ayat tersebut dianalisis dengan melihat pertautannya dengan ayat-ayat

44 https://thkhusus.wordpress.com/2010/ 01/03/tafsir-lughawy/diakses tanggal 1 Januari 2017.

\footnotetext{
45 Pusat Bahasa Departemen Pendidikan dan Kebudayaan, Kamus Besar Bahasa Indonesia,... hal 1077

46
}

http://www.jurnalhukum.com/penafsiranhukum-interpretasi-hukum/diakses tanggal 2 Desember 2018

47 Abdul Muin Salim. 2002. Fiqih Siyasah, Konsepsi Kekuasaan Politik Dalam AlQur'an. cet III; Jakarta: Raja Grafindo. hlm. 4951. lainnya yang ada di sekitarnya atau kedudukannya dalam surah.

Dalam pembahasan Ulumul Qur'an, ilmu tentang kaitan ayat dan surah atau ayat dan ayat disebut ilmu munasabah. Secara terminologi atau istilah yang diberikan para ulama, munâsabah adalah ilmu yang mengaitkan bagian-bagian awal ayat dan akhirnya, mengaitkan lafadz umum dan khusus atau hubungan antar ayat yang terkait dengan sebab akibat, 'illat dan ma'lul, kemiripan ayat, pertentangan (ta'arud) dan sebagainya. Sebegitu eratnya hubungan antara bagian satu dengan bagian yang lain dalam Al-Qur'an dari unsur paling terkecil hingga menjadi seperti bangunan yang kukuh, utuh, sempurna dan sesuai istilah imam az-Zarkasy bagian-bagiannya tersusun harmonis. Lebih jauh lagi az-Zarkasyi menempatkan ilmu munâsabah adalah satu dari sekian banyaknya segi kemukjizatan Al-Qur'an (i'jaz AlQur'an). ${ }^{48}$

Di dalam pustaka berbahasa Indonesia dipakai beberapa istilah yang bervariasi sebagai sinonim dari munâsabah, seperti kesesuaian, hubungan, korelasi, kaitan, pertalian, tanasub, ${ }^{49}$ dan di antaranya tetap memakai istilah munâsabah itu sendiri.

Penggunaan tehnik ini mengacu dari kenyataan Al-Qur'an sebagai kitab suci yang memiliki sistematika yang utuh dan padu dan disusun oleh Allah yang Mahabijaksana lagi Mahatahu. Tentu saja makna yang diperoleh berdasarkan tehnik ini terbatas sesuai dengan kemampuan intelektual mufassir. Siapa pun yang

${ }^{48}$ Badr ad-dîn Muhammad az-Zarkasyî. Al-Burhân fi 'Ulûm Al-Qur'an. ed. Muhammad Abû al-Fadhl Ibrâhim.' Isâ al-Bâb al-Halabî, cet 1, t.th., juz I, hlm. 35.

49 Nashruddin Baidan. 2011. Wawasan Baru Ilmu Tafsir. Pustaka Pelajar, Yogyakarta, cet II. hlm. 192. 
mencoba mengaitkan berbagai sebab tanpa ilmu yang memadai, berarti ia telah memaksakan diri untuk melakukan sesuatu yang tidak semestinya sehingga hanya akan menghasilkan hubungan yang tidak akurat. Dengan demikian, tentu tidak akan ditemukan pembicaraan yang indah, apalagi yang terbaik Dalam hal ini, harus dipahami bahwa bagai manapun Al-Qur'an turun selama lebih dari dua puluh tahun dengan memuat hukum yang berbeda. Kondisi itulah yang tidak mudah kita hubungkan sebagian dengan yang lain secara paksa.

Ilmu munasabah mulai disadari keutamaannya ketika masa Abu Bakar an-Naisaburi (w. $324 \mathrm{H}$ ), pada masa keemasan Islam (abad I-IV H), yaitu ketika terjadi lonjakan besar dalam perkembangan ilmu-ilmu keislaman. ${ }^{50}$ Ketika dihadapkan padanya ayat AlQur'an kepadanya selalu ia katakan, "Mengapa ayat ini diletakkan di samping ayat ini dan apa rahasia diletakannya surat ini di samping surat itu", begitulah yang terjadi berulangulang seperti dikutip oleh az-Zarkasyi dari asy-Syahrâbânî. Terlepas dari pro dan kontra atas apa yang dilakukan Naisaburi, tindakannya merupakan sebuah kejutan dan langkah baru dalam dunia tafsir saat itu. Atas prestasi Naisaburi dalam memelopori ilmu munâsabah ia mendapat gelar sebagai bapak ilmu munâsabah. ${ }^{51}$

Dalam pembagiannya munâsabah ini, para ulama juga berbeda pendapat mengenai pengelompokan munâsabah dan jumlahnya, hal ini dipengaruhi bagaimana seorang ulama tersebut

50 Nashruddin Baidan. 2011. Wawasan Baru Ilmu Tafsir. Pustaka Pelajar, Yogyakarta, cet II. hlm 186.

${ }^{51}$ M. Nor Ichwan. 2008. Studi Ilmu-Ilmu Al-Qur'an. Semarang: RaSAIL Media Group, hlm 53. memandang suatu ayat dari segi yang berbeda. Menurut Chaerudji A. Chalik munâsabah dapat dilihat dari dua sisi, yaitu sifat dan materinya. ${ }^{52}$

\section{a. Munasabah dari sisi Sifat,}

Dilihat dari sisi sifatnya, terbagi menjadi dua bagian, yaitu:

Pertama Dza ahir al-irtibât, yaitu persesuaian atau kaitan yang tampak jelas, karena kaitan kalimat yang satu dengan yang lain erat sekali sehingga yang satu tidak bisa menjadi kalimat yang sempurna bila dipisahkan dengan kalimat lainnya, seolah-olah ayat tersebut merupakan satu kesatuan yang sama. Misalnya, dapat kita cermati ayat Surat Al-A'raf Ayat 26.

$$
\begin{aligned}
& \text { يَا بَنِي آَدَمَ قَدْ أَنْزَلْنَا عَلَيْكُمْ } \\
& \text { لِبَاسًا يُوَارِي سَوُْآتِكُمْ وَرِيشَّاسِ }
\end{aligned}
$$

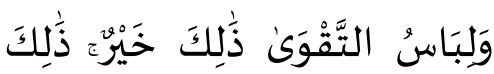

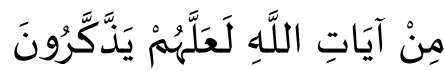

Munâsabah dalam ayat di atas tampak jelas, hubungan antara pakaian biasa dan pakaian taqwa dalam menutupi aurat manusia. Allah telah memberi kenikmatan berupa pakaian,

52 Acep Hermawan. 2011. 'Ulumul Qur'an. Bandung: PT Remaja Rosdakarya, hlm. 125. 
libâs. Ada banyak jenis pakaian yang ada di alam semesta, namun hanya satu di hadapan Allah pakaian yang dikaruniai yaitu pakaian taqwa, libâs attaqwâ. Hal tersebut terlihat dari kalimat żâlika khair. Adanya tambahan keterangan tersebut, makin jelas bahwa pakaian yang efektif yang diperintahkan Allah dalam memelihara seseorang dari hal-hal negatif lahir-batin, terhindar dari godaan syaitan dan perbuatan keji adalah pakaian taqwa. Yaitu sikap mental yang selalu tunduk dan patuh melak-sanakan perintah dan meninggalkan larangannya agar terhindar dari siksa neraka. ${ }^{20}$

Kedua khafî al-irtibâț, yaitu munâsabah yang tampak samar, sehingga tidak tampak adanya hubungan antara keduanya, bahkan seolah-olah masingmasing ayat/surat berdiri sendiri, baik karena yang pertama di'ațafkan kepada yang lain maupun karena yang pertama bertentangan dengan yang lain. Misalnya dalam Aurat Al-Baqarah ayat 189 dan 190. Allah berfirman, Mereka bertanya kepadamu tentang bulan sabit. Katakanlah: "Bulan sabit itu adalah tanda-tanda waktu bagi manusia dan (bagi ibadat) haji; dan bukanlah kebajikan memasuki rumah-rumah dari belakangnya, akan tetapi kebajikan itu ialah kebajikan orang yang bertakwa. dan masuklah ke rumah-rumah itu dari pintu-pintunya; dan bertakwalah kepada Allah agar kamu beruntung. (QS. AlBaqarah: 189) Ayat tersebut mempunyai korelasi dengan ayat setelahnya. "Dan perangilah di jalan Allah orang-orang yang memerangi kamu, (tetapi) janganlah kamu melampaui batas, karena Sesungguhnya Allah tidak menyukai orang-orang yang melampaui batas. (QS. Al-Baqarah: 190)

Munâsabah antara keduanya adalah ketika musim haji umat Islam dilarang berperang, namun jika umat Islam diserang terlebih dahulu, maka larangan berperang menjadi gugur meskipun pada musim haji dan diperbolehkan melawan serangan tersebut selama tidak melampaui batas. ${ }^{53}$

\section{b. Munasabah dari sisi Materi.}

Banyak mufassir yang memiliki konsen dalam hal munâsabah Al-Qur'an saat ini, seperti Quraish Shihab. Ia mengklasifikasikan korelasi kalimat, ayat, surat dalam teks Al-Qur'an dalam tujuh point penting. ${ }^{54}$ Yaitu:

1. Munasabah antara surah dengan surah

2. Munasabah antara nama surah dengan kandunganya

3. Munasabah antara ayat dengan ayat dalam surah yang sama.

4. Munasabah antara ayat dengan ayat dan hubungan antara satu sama lain.

5. Munasabah antara akhir suatu surat dengan awal surat berikunya.

6. Munasabah antara kalimah dengan kalimah dalam satu surah.

7. Munasabah awal uraian surat dengan akhirnya

Berikut ini Penulis akan menguraikan tiga contoh saja, interpretasi sistemik atau munasabah dari sisi materi diatas.

b.1. Munasabah Antara Surat dengan Surat.

Salah satu contoh yang dapat diajukan di sini adalah munasabah yang dapat ditarik pada tiga surat beruntun, masing-

53 Acep Hermawan. 'Ulumul Qur'an...hlm 126.

${ }^{54}$ M. Quraish Syihab. 2013. Mukjizt Al Qur'an Ditinjau dariAspek Kebahasaan, Isyarat Ilmiah dan Pemberitaan Ghaib. Jakarta, Mizan. hlm 36. 
masing QS. Al-Fatihah (1), QS. AlBaqarah (2), dan QS. Ali-Imran (3). ${ }^{55}$ Satu surah berfungsi menjelaskan surat sebelumnya, misalnya di dalam Surat Al-Fatihah (QS: 1: 6) disebutkan:

$$
\text { إهدنا الصراط المستقيم }
$$

.."Tunjukilah kami jalan yang lurus",

Lalu dijelaskan dalam Surat Al-Baqarah (QS: 2: 2), bahwa jalan yang lurus itu ialah mengikuti petunjuk AlQur'an, sebagaimana disebutkan:

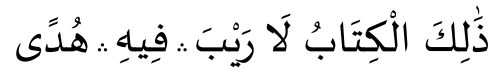

$$
\begin{aligned}
& \text { لِلْمُتَّقَينَ }
\end{aligned}
$$

..Kitab (Al-Qur'an) ini tidak ada keraguan padanya, petunjuk bagi mereka yang bertakwa" (QS. Al-Baqarah:

2)

Keserasian hubungan atau munasabah antar surat ini pada hakikatnya memperlihatkan kaitan yang erat dari suatu surat dengan surat lainnya. Bentuk munasabah yang tercermin pada masing-masing surat, kelihatannya memperlihatkan kesatuan tema. Salah satunya memuat tema sentral, sedangkan surat-surat lainnya menguraikan sub-sub tema berikut perinciannya, baik secara umum maupun parsial.

\section{b.2. Munasabah Antara Nama Surat} dengan Kandungan Isinya

Nama satu Surat pada dasarnya bersifat tauqifi (tergantung pada petunjuk Allah dan Nabi-Nya). Namun

55 Jalal ad-Din al-Suyuthi. Tanâsuq adDurar fi Tanâsub as-Suwar. hlm. 76. beberapa bukti menunjukkan bahwa suatu Surat terkadang memiliki satu nama dan terkadang dua nama atau lebih. Tampaknya ada rahasia dibalik nama tersebut. Para ahli tafsir sebagaimana yang dikemukakan oleh al-Sayuthi melihat adanya keterkaitan antara nama-nama Surat dengan isi atau uraian yang dimuat dalam suatu Surat. Kaitan antara nama surat dengan isi ini dapat di identifikasikan sebagai berikut $^{56}$ :

a. Nama diambil dari urgensi isi serta kedudukan Surat. Nama Surat AlFatihah disebut dengan umm AlKitab karena urgensinya dan disebut dengan Al-Fatihah karena kedudukannya.

b. Nama diambil dari perumpamaan, peristiwa, kisah atau peran yang menonjol, yang dipaparkan pada rangkaian ayat-ayatnya; sementara di dalam perumpamaan, peristiwa, kisah atau peran itu sarat dengan ide. Di sini dapat disebut namanama Surat: Al-'Ankabut, Al-Fath, Al-Fil, Al-Lahab dan sebagainya.

c. Nama sebagai cerminan isi pokoknya, misalnya al-Ikhlas karena mengandung ide pokok keimanan yang paling mendalam serta kepasrahan: al-Mulk mengandung ide pokok hakikat kekuasaan dan sebagainya.

d. Nama diambil dari tema spesifik untuk dijadikan acuan bagi ayatayat lain yang tersebar diberbagai surat. Contoh Al-Hajj (dengan spesifik tema haji), al-Nisa' (dengan spesifik tema tentang tatanan kehidupan rumah tangga). Kata Nisa' yang berarti kaum wanita adalah irrig keharmonisan rumah tangga.

$\begin{array}{rr}56 \quad \text { Acep } & \text { Hermawan. 'Ulumul } \\ \text { Qur'an...hlm 128. } & \end{array}$


e. Nama diambil dari huruf-huruf tertentu yang terletak dipermulaan surat, sekaligus untuk menuntut perhatian khusus terhadap ayat-ayat di dalamnya yang memakai huruf itu. Contohnya: Thaha, Yasin, Shad, dan Qaf.

\section{b.3. Munâsabah antara ayat dengan ayat dalam satu surat.}

Sebagai contoh jenis ini dapat diperhatikan ayat-ayat pada awal Surat Al-Baqarah mulai ayat 1-20. Ayat-ayat tersebut dapat diklasifikasikan menjadi tiga kelompok: a) keimanan, merupakan ayat $1-5$; b) kekufuran, perhatikan ayat 6-7; dan c) kemunafikan dari ayat 8-20. Dalam membedakan ketiga kelompok tersebut secara jelas dengan menarik hubungan antara ayat-ayat tersebut. Misalnya dengan menyebut sifat-sifat mukmin, kafir dan munafik secara runtun dan berdekatan maka akan memberikan pemahaman yang lebih gamblang dan utuh tentang watak ketiga golongan itu. Oleh karenanya akan amat masuk akal ketika ketiga golongan tersebut disebut secara berurutan, sehingga memudahkan dalam menyerap informasi. ${ }^{57}$

\section{D.1.d. Interpretasi Sosio Historis}

Interpretasi Sosio Historis mengandung pengertian penelaahan suatu objek (dalam hal ini ayat AlQur'an) berdasarkan keadaan, perkembngan masyarakat ketika ayat itu diturunkan dengan melakukan pendekatan secara kesejarahan (historis). Ayat-ayat Al-Qur'an ditafsirkan dengan pendekatan sejarah berkenaan dengan kehidupan sosio kultural masyarakat Arab ketika ayat

${ }^{57}$ Jalal ad-Din al-Suyuthi. Tanâsuq AdDurar fi Tanâsub As-Suwar. hlm. 78. diturunkan. Hal ini berpijak pada suatu landasan faktual bahwa terdapat ayatayat Al-Qur'an yang diturunkan berkaitan dengan peristiwa-peristiwa atau kasus-kasus tertentu. ${ }^{58}$ Teknik semacam ini sudah dikenal dan bahkan dipergunakan sejak masa sahabat.

Teknik interpetasi ini dikenal dalam Ulumul Qur'an dengan penafsiran berdasarkan Asbabun Nuzul. Atau sebab-sebab turunnya (suatu ayat) Al-Qur'an. Dalam penafsiran tersebut dibahas mengenai latar belakang atau sebab-sebab suatu atau beberapa ayat Al-Qur'an diturunkan. Pada umumnya, Asbabun Nuzul memudahkan para mufassir untuk menemukan tafsir dan pemahaman suatu ayat dari balik kisah diturunkannya ayat itu. Selain itu, ada juga yang memahami ilmu ini untuk menetapkan hukum dari hikmah di balik kisah diturunkannya suatu ayat. Mengetahui Asbabun Nuzul suatu ayat dapat membantu Mufassir memahami makna ayat. Pengetahuan tentang Asbabun Nuzul suatu ayat dapat memberikan dasar yang kukuh untuk menyelami makna suatu ayat AlQur'an.

Pengetahuan Asbābun-Nuzūl merupakan hal yang amat penting dalam memahami Al-Qur'ān dan menafsirinya. Seperti yang sudah ditetapkan para ulama, bahwa AlQur'ān itu diturunkan dengan dua bagian. Satu bagian diturunkan secara langsung, dan bagian ini merupakan mayoritas Al-Qur'ān. Bagian kedua diturunkan setelah ada suatu kejadian atau permintaan, yang turun mengiringi selama turunnya wahyu, yaitu selama tiga belas tahun. Bagian kedua inilah yang dibahas berdasarkan sebab turunnya. Sebab, mengetahui sebab

58 Abdul Muin Salim. Fiqih Siyasah, Konsepsi Kekuasaan Politik Dalam Al-Qur'an. hlm. 49-51. 
turunnya dan seluk-beluk yang melingkupi nash, akan membantu pemahaman dan apa yang akan dikehendaki dari nash itu. ${ }^{59}$

Sebagai contoh di sini dapat dikemukakan tentang penginterpretasian kata al-tahlukah pada ayat berikut:

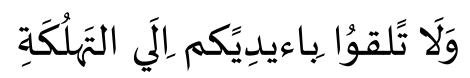

Menurut riwayat Ibnu Jarir, menjelang turunnya ayat tersebut diatas ada suiatu kasus seorang sahabat membagi-habiskan harta perbekalan perangnya kepada sahabat lainnya. Dengan demikian maka yang dimaksud al-tahlukah dalam ayat ini adalah membiarkan diri terpuruk dalam kesengsaraan atau kelaparan. ${ }^{60}$

Adapun ayat yang diturunkan karena suatu peristiwa menurut AzZarqani ada tiga bentuk. Pertama, peristiwa khushümah (pertengkaran) yang sedang berlangsung, semisal perselisihan antara kelompok Aus dan Khazraj yang disebabkan oleh rekayasa kaum Yahudi sampai mereka berteriak: "as-silāh, as-silāh" (senjata, senjata). Dari kejadian ini turunlah beberapa ayat dari surat Ali 'Imrān yang di mulai dari ayat 100. Kedua, peristiwa berupa kesalahan seseorang yang tidak dapat di terima akal sehat. Seperti orang yang masih mabuk mengimani salat sehingga ia salah dalam membaca surat alKāfirūn. Kemudian turunlah ayat dari surat an-Nisā: 43. Ketiga, peristiwa mengenai cita-cita dan harapan, seperti muwāafaqāt (persesuaian, kecocokan) Umar RA. Aku ada persesuaian dengan Tuhanku dalam tiga perkara. Aku

59 Yusuf Al-Qardawi. 2000. Bagaimana Berinterakasi dengan Al-Qur`an. terj. Kathur Suhardi, Jakarta: Pustaka al-Kausar, hlm. 267.

60 Abd Al-Rahmān Jalāl al-Dīn alSyuyūhī. al-Durr al-Mantsūr fi al-Tafsīr al-Matsūr. hlm. 5, hlm. 500. katakan kepada Rasulullah bagaimana kalau Maqām Ibrahim kita jadikan tempat salat, maka turunlah ayat :Dan jadikanlah sebahagian maqām Ibrahim tempat salat" (AlBaqarah: 125). Dan aku berkata wahai Rasulullah: "Sesungguhnya di antara orang-orang yang menemui istri-istrimu ada yang baik (Al-barru) dan ada yang jahat (Al-fäjir), bagaimana kalau anda memerintahkan kepada mereka untuk membuat hijāb (tabir). Kemudian turunlah ayat $h i j \bar{a} b$, yakni ayat dari surat $A l-A h z \bar{a} b$ ayat $53 .{ }^{61}$

Menurut Az-Zarqani tidak semua ayat atau beberapa ayat mempunyai $a s b \bar{a} b$ an-nuzūl, diantaranya ayat yang berbicara mengenai kejadian atau keadaan yang telah lampau dan akan datang, semisal kisah nabi-nabi dan umat terdahulu dan juga kejadian tentang as-sā'ah (kiamat) dan yang berhubungan dengannya. Ayat-ayat seperti ini banyak terdapat dalam AlQur`an. $^{62}$

Menurut Anin Summa, paling sedikit ada tiga kemungkinan mengapa tidak seluruh ayat Al-Qur'an dapat diketahui sebab-sebab yang melatarbelakangi penurunannya. Dan masing-masing kemungkinan itu terkait erat antara satu dengan yang lain. Kemungkinan pertama tidak semua hal yang bertalian dengan proses turun AlQur'an ter-cover oleh para sahabat yang langsung menyaksikan proses penurunan wahyu Al-Qur'an. Kedua, penyaksian para sahabat terhadap halhal yang berkenaan dengan proses penurunan wahyu Al-Qur'an tidak semuanya dicatat. Kalaupun kemudian dicatat, pencatatan itu sendiri dapat dikatakan sudah terlambat. Sehingga, kalaupun semua proses penurunan AlQur'an itu secara keseluruhan terekam

\footnotetext{
${ }^{61}$ Az-Zarqani. Manāhil al- 'Urfān. hlm. 96

${ }^{62}$ Az-Zarqani. Manāhil al- 'Urfān. hlm. 97
} 
oleh para sahabat, tentu ada yang hilang dari ingatan mereka mengingat keterlambatan pencatatan itu tadi. Ketiga, terbuka lebar kemungkinan ada sejumlah ayat-ayat Al-Qur'an yang penurunannya memang tetap dipandang tepat dengan atau tanpa dikaitkan langsung dengan suatu peristiwa/untuk mengenali sebab nuzul ayat, selain bisa ditelusuri melalui sejumlah kitab tafsir, atau dengan pertanyaan yang mendahuluinya. $^{63}$

\section{D.2. Potensi Deviasi Penafsiran Al- Qur'an Dalam Tinjauan Ilmu Dakhil.}

Para penafsir Al-Qur'an telah menawarkan berbagai macam metode dan teknik penafsiran untuk memahami Al-Quran. Metode dan teknik tersebut sangat bergantung pada kecenderungan dan minat kelimuan sang penafsir. Dari perbedaan kecenderungan keilmuan tersebut lahirnya bermacam-macam madzhab tafsir seperti tafsir fiqhi, tafsir ilmi, tafsir adabi ijtima'i, tafsir hermeneutis dan lain sebagainya.

Dari sekian metode yang ditawarkan oleh berbagai mufassir dari zaman klasik hingga modernkontemporer, sangat sulit untuk menentukakn metode yang mana yang paling pas dan benar. Namun yang pasti semua penafsir Al-Qur'an semuanya menginginkan agar karya tafsirnya dapat mengungkap makna Al-Qur'an dengan sebenar-benarnya. Penulis yakin bahwa tidak ada seorang mufassirpun yang menafsirkan Al-Qur'an dengan tujuan memaknai Al-Qur'an secara salah. Namun, kemungkinan kesalahan dalam penafsiran tentu akan banyak ditemukan karena mengungkap makna

\footnotetext{
${ }^{63}$ Muhammad Amin Suma. 2013. Ulumul
} Qur`an. Jakarta: Rajawali Pers, hlm. 209.
Al-Qur'an tidaklah semudah
membalikkan telapak tangan.

Berbicara tentang salah dan benarnya sebuah tafsir merupakan hal yang tidak mudah. Sebab sejak meninggalnya Nabi, tidak ada lagi seseorang yang dipandang memiliki otoritas untuk menentukan yang mana sebuah tafsir itu dikatakan benar atau salah. Pertanyaan yang muncul adalah siapakah yang berhak menilai bahwa sesuatu tafsir dikatakan benar benar atau salah? Namun, bukan berarti tidak ada jalan untuk menemukan kesalahankesalahan dalam tafsir. Langkahlangkah yang bisa ditempuh adalah dengan melihat ijma' ulama-ulama tafsir ketika berbicara tentang sebabsebab kesalahan dalam menafsirkan AlQur'an. ${ }^{64}$

Al-Zahabi misalnya mengatakan bahwa agar seorang mufassir agar tidak terjatuh dalam kesalahan, maka ia harus meninggalkan hal-hal berikut:

1. Terburu-buru menafsirkan AlQur'an tanpa mengetahui aturan-aturan kebahasaan dan ushul al-syari'ah.

2. Terlalu mendalami sesuatu yang dirahasiakan oleh Allah sep-erti ayat-ayat mutasyabihat.

3. Menafsirkan Al-Qur'an dengan hawa nafsu dan dugaan-dugaan semata.

4. Penafsiran yang ditundukkan pada mazhab yang rusak (mazhab al-fasid).

5. Tafsir yang dipotong-potong (parsial) tanpa adanya dasar argumen yang jelas. ${ }^{6}$

64 Abdul Halim. 2014. "Sebab-sebab Kesalahan dalam Tafsir”. Jurnal Syahadah, Universitas Islam Indragiri Tembilahan, Vol 2. N0.1 April, hlm. 72.

65 Muhammad Husain al-Zahabi. alTafsir wa al-Mufassirun. juz.1, hlm. 275. 
Meskipun para ulama telah
menetapkan berbagai macam persyaratan sebagai kompetensi untuk menafsirkan Al-Qur'an, namun ijtihad mereka dengan dipengaruhi oleh kemampuan daya tangkap, pengetahuan bahasa, minat kajian, referensi teks, afiliasi aliran, adat istiadat, letak geografi mereka yang berbeda menjadikan cacat tafsir ini sulit untuk dihindari. Kekeliruan dalam penafsiran inilah yang dikenal dalam ilmu tafsir dengan istilah $a l-D a k h \hat{\imath} l^{66}$.

Ilmu Dakhîl memang relatif belum terlalu populer. Ilmu ini baru disusun secara sistematis dan diajarkan di Al-Azhar Kairo Mesir pada sekitar tahun delapan puluhan. Di Universitas Al Azhar Mesir, mata kuliah al-Dakhîl fi al Tafsir dimasukkan sebagai materi pokok dalam jurusan Tafsir Fakultas Ushuluddin Azhar Mesir sampai saat ini. Mata kuliah ini menduduki posisi yang sangat sentral bagi penggiat studi tafsir dan Ulumul Qur'an mengingat banyak produk tafsir dari para mufassir yang mengandung kelemahankelemahan. Kekeliruan tersebut hanya bisa dikoreksi secara metodik dan terarah dengan mengenal Ilmu Dakhil (Metode kritik Tafsir). Sebagaimana halnya dengan mengkritisi hadis-hadis yang beredar dengan menerapkan Ilmu Musthalahul Hadis (Metode Kritik Hadis, Sanad dan Matan).

Sejarah mengungkapkan bahwa kekeliruan dalam menafsirkan AlQur'an juga dilakukan sebagian

${ }^{66}$ Makna umum al-Dakhîl fî al-tafsîr secara istilah adalah kekeliruan dalam menafsirkan Al-Qur'an. Dakhîl dalam tafsir dapat diartikan suatu aib dan cacat yang sengaja ditutup-tutupi dan disamarkan hakikatnya serta disisipkan di dalam beberapa bentuk tafsir Al-Qur'an yang otentik. Akibat penyembunyian dan penyamaran ini, usaha untuk mengetahui dan mengungkapannya membutuhkan suatu penelitian.. sahabat. Kalau pada masa Rasulullah Shalalahu'alaihi wa Sallam para sahabat menanyakan persoalanpersoalan yang tidak jelas kepada beliau, maka setelah wafatnya, mereka terpaksa melakukan ijtihad, khususnya mereka yang mempunyai kemampuan semacam 'Ali bin Abi Thalib, Ibnu 'Abbas, Ubay bin Ka'ab, dan Ibnu Mas'ud. Sementara sahabat ada pula yang menanyakan beberapa masalah, khususnya sejarah nabi-nabi atau kisahkisah yang tercantum dalam Al-Qur'an kepada tokoh-tokoh Ahlul-Kitab yang telah memeluk agama Islam, seperti 'Abdullah bin Salam, Ka'ab Al-Ahbar, dan lain-lain. Inilah yang merupakan benih lahirnya Israiliyat. ${ }^{\text {i67 }}$

Sekalipun para sahabat orangorang Arab dan berbahasa Arab, tetapi pengetahuan mereka tentang bahasa Arab berbeda-beda. Pengetahuan sahabat tentang sastra Arab, gaya bahasa, adat istiadat dan kata-kata yang terdapat dalam Al-Qur'an juga mempunyai tingkatan yang berbeda. Ada sababat yang sering mendampingi Nabi Muhammad Shalallahu'alaihi wa Sallam, sehingga banyak mengetahui sebab-sebab ayat-ayat Al-Qur'an diturunkan dan ada pula yang jarang mendampingi beliau. Pengetahuan tentang sebab-sebab Al-Qur'an diturunkan itu, sangat diperlukan untuk mentafsirkan Al-Qur'an. Karena itu sahabat-sahabat yang banyak pengetahuan mereka tentang sebab AlQur'an diturunkan itu, lebih mampu mentafsirkan ayat-ayat Al-Qur'an dibandingkan dengan yang lain.

Sebagai contoh kekeliruan sahabat dalam menafsirkan ayat, dapat dikemukakan sebagai berikut.

${ }^{67}$ Muhammad Abu Syuhbah. 1408 H. Al Israiliyat wa al Maudhu'at fi Kutubit Tafsir. Kairo, Maktabah As-Sunnah. hlm. 20. 
Diriwayatkan bahwa Khalifah Umar bin Khathab telah mengangkat Qudamah sebagai gubernur Bahrain. Dalam suatu peristiwa datanglah Jarud mengadu kepada Khalifah Umar, bahwa Qudamah telah meminum khamar dan mabuk. Umar berkata: "Siapakah orang lain yang ikut menyaksikan perbuatan tersebut?" Jarud kemudian menukas: "Abu Hurairah telah menyaksikan apa yang telah kukatakan". Khalifah Umar memanggil Qudamah dan mengatakan: "'Ya Qudamah! Aku akan mendera engkau!. Lalu berkata Qudamah: "Seandainya aku meminum khamar sebagaimana yang mereka katakan, tidak ada suatu alasan pun bagi engkau untuk menderaku". Umar bertanya: "Kenapa?" jawab Qudamah: "Karena Allah telah berfirman dalam surat $\mathrm{Al}$ Maidah ayat 93. Artinya: Tidak ada dosa bagi orang-orang yang beriman dan menengerjakan amalan yang saleh, karena memakan makanan yang telah mereka makan dahulu, apabila mereka bertakwa serta beriman dan mengerjakan amalan-amalan yang saleh, kemudian mereka tetap bertakwa dan beriman, kemudian mereka (tetap juga) bertakwa dan berbuat kebajikan. Dan Allah menyukai orang-orang yang berbuat kebajikan."

Sedang saya adalah orang yang beriman, mengerjakan amal saleh, kemudian bertakwa dan beriman, saya ikut bersama Nabi Muhammad Shalallahu'alaihi wa Sallam. dalam perang Badar, perang Uhud, perang Khandaq dan peperangan yang lain." Umar berkata: "Apakah tidak ada di antara kamu sekelian yang akan membantah perkataan Qudamah?. Berkata lbnu Abbas: "Sesungguhnya Ayat 93 Surah Al-Ma'idah diturunkan sebagai melindungi umat di masa sebelum Ayat 90 ini diturunkan, karena Allah berfirman: Surat Al-Ma'idah Ayat 90. Artinya: Hai orang-orang yang beriman, sesungguhnya (meminum khamar, berjudi (berkorban untuk) berhala, mengundi nasib dengan panah, adalah perbuatan keji; termasuk perbuatan syaitan. Kerana itu jauhilah perbuatan-perbuatan itu agar mendapat keberuntungan (kejayaan)".

Berkata Umar: "Benarlah lbnu Abbas."

Dari keterangan di atas dapat diambil kesimpulan bahwa lbnu Abbas lebih mengetahui sebab-sebab diturunkannya ayat 93 Surah AlMa'idah dibanding dengan Qudamah. Sebab menurut riwayat Ibnu Abbas, bahwa setelah Ayat 90 Surat AlMa'idah diturunkan, sahabat-sahabat saling menanyakan tentang keadaan para sahabat yang telah meninggal, padahal mereka dahulu sering meminum khamar seperti Sayidina Hamzah, bapak saudara Nabi yang gugur sebagai syuhada pada perang Uhud. Ada sahabat yang mengatakan bahawa Hamzah tetap berdosa karena perbuatannya yang telah lalu itu. karena itu turunlah Ayat 93 Surah Al AlMa'idah, yang menyatakan bahawa umat Islam yang meninggal sebelum turunnya ayat 90 Surah (5) Al Maa'idah tidak berdosa karena meminum khamar itu. Tetapi umat sekarang berdosa meminumnya.

Contoh lain kekeliruan penafsiran sahabat yang terjadi pada masa Rasullallah S.A.W. Yaitu ayat dalam Surat Al-Baqarah 187 yang artinya seperti di bawah ini;

"Makan dan minumlah hingga jelas bagimu (perbedaan) antara benang putih dan benang hitam, yaitu fajar. Kemudian sempurnakanlah puasa sampai (datang) malam.

Ayat di atas mendapat persepsi yang keliru dari seorang sahabat Nabi Shalallahu'alaihi wa Sallam, yaitu 'Adiy ibn Hâtim. Sebagaimana yang 
diceritakannya bahwa ia berkata; "Ketika ayat (Makan dan minumlah hingga jelas bagimu (perbedaan) antara benang putih dan benang hitam) turun (dengan tanpa kalimat Min alFajr) saya mengambil dua utas igal, ${ }^{i}$ igal pertama berwarna hitam dan yang kedua berwarna putih. Saya meletakkan keduanya di bawah bantal saya. Saya tidak dapat membedakan warna keduanya dengan jelas. Pada pagi harinya saya menghadap Rasulullah Shalallahu'alaihi wa Sallam dan melaporkan yang saya lakukan. Beliau bersabda, 'Kalau begitu, bantalmu sangat lebar. Maksud ayat adalah terangnya cahaya siang dari kegelapan malam.' "

Ibnu Katsir dalam menafsirkan kalimat Kalau begitu, bantalmu sangat lebar menyatakan bahwa maksud benang putih adalah cahaya siang sedang maksud benang hitam adalah kegelapan malam. Dengan demikian seandainya bantal 'Adi ibn Hatim dapat memuat cahaya siang dan kegelapan malam, maka pastilah bantalnya itu seluas ufuk timur dan barat. ${ }^{\text {ii }}$

Dakhîl yang dilakukan oleh sahabat seharusnya menjadi pelajaran bagi semua kaum muslimin. Bila seorang sahabat yang bertemu dan bergaul dengan Nabi, melihat dan mengetahui sebab-sebab turunnya AlQur'an dan memperoleh berkat kenabian masih salah dalam memahami sebagian Al-Qur'an, maka apatah lagi kaum muslimin yang hidup setelah priode sahabat! Kesalahan mereka seharusnya memperingatkan kaum muslimin bahwa tafsir Al-Qur'an adalah masalah besar, penting dan krusial. Karena itu penafsiran Al-Qur'an harus dilakukan dengan penuh ketelitian, kehati-hatian dan melengkapi syaratsyaratnya. $^{68}$

Adalah Prof. Dr. Ibrahim Khafilah, guru besar Universitas Al Azhar Mesir yang secara spesifik mempopulerkan istilah dakhil. Beliau menetapkan sejumlah landasan teoritis/metodologi terkait dengan Ilmu Dakhil. Dalam bukunya al-Dakhîl fi al Tafsir beliau menulis bahwa bentuk penafsiran Al-Qur'an secara garis besarnya ada dua yaitu al-ma'tsûr atau riwayat dan al-ra'yi atau akal. AlMa'tsûr mencakup Al-Qur'an, hadis, pendapat sahabat dan pendapat tabiin. Penggunaan al-ma'tsûr dalam penafsiran Al-Qur'an didahulukan daripada penggunaan al-ra'yi. Dan dalam penggunaan al-ma'tsûr mengikuti susunannya, yaitu mencari penafsiran Al-Qur'an di dalam AlQur'an itu sendiri. Bila tidak ditemukan, maka mencarinya dalam hadis yang layak dijadikan hujjah dan demikian seterusnya. Tetapi tidak semua al-ma'tsûr itu sahih, dan tidak semua al-ma'tsûr yang sahih memenuhi persyaratan-persyaratan untuk dijadikan hujjah dalam tafsir, dan tidak semua tafsir bi al-ra' yi itu benar.

Tiga bentuk penafsiran yang termasuk kategori al-Dakhîl adalah (1) tafsir bi al-ma'tsûr yang tidak sahih atau tidak valid dalam periwayatannya, (2) tafsir bi al-ma'tsûr yang sahih periwayatannya tetapi tidak memenuhi persyaratan-persyaratan untuk dijadikan hujjah, dan (3) tafsir bi al-ra'yi yang keliru salah dan tidak dapat diterima. Kerena menafsirkan berdasarkan hawa nafsu atau afiliasi mazhab sang penafsir, tanpa mengindahkan syarat-syarat metodologi tafsir bi ar-ra'yi, atau dikarenakan kurangnya syarat untuk

${ }^{68}$ Ibrâhîm Khalîfah. 1404 H. al-Dakhîl fì al-Tafsîr. Kairo: Dâr al-Bayân, Jilid 1, hlm. 21-22. 
menjadi seorang mujtahid. Sedang penafsiran yang tepat dan benar disebut al-ashîl. ${ }^{69}$

Berikut dinukilkan beberapa sebab Dakhil al Ma'tsur yaitu kekeliruan dalam penafsiran riwayat yang diidentifikasi oleh Prof Ibrahim Khalifah dalam sembilan jenis. (1) Menafsirkan Alqurân dengan menggunakan Hadis Nabi yang lemah dan palsu. (2). Pendapat sahabat dan tabiin yang sanadnya lemah atau dipalsukan. (3). Menggunakan riwayat Isrâiliyyât yang bertentangan dengan pokok agama Islam ataupun yang tidak kontradiktif akan tetapi Alqurân dan hadis sahih tak sekalipun menyinggung hal tersebut. Baik itu diriwayatkan oleh sahabat maupun tabiin. (4) Menafsirkan Alqur'an dengan pendapat sahabat yang berbeda dengan pendapat sahabat yang lain, sedang perbedaannya sangat tajam, sehingga tidak diketahui mana yang benar. (5) Menafsirkan Al-Qur'an dengan pendapat tabiin yang tidak valid, seperti menafsirkan Al-Qur'an dengan hadis mursal yang palsu atau sanadnya daif. (6) Menafsirkan Al-Qur'an dengan hadis mursal yang matannya mengenai Israiliyat. Sekalipun hadis mursal itu sesuai dengan Al-Qur'an dan hadis sahih, selama ia tidak diperkuat oleh sesuatu yang mengangkatnya ke posisi hadis hasan li ghairih maka tetap dikategorikan dalam dakhil al ma'tsur (7) Menafsirkan Al-Qur'an dengan salah satu bentuk ashîl al-naqli dari empat bentuk ashîl al-naqli pertama, namun materinya kontradiktif, tidak dapat dikompromikan dengan logika positif. (8) Menafsirkan Al-Qur'an dengan salah satu bentuk ashîl al-naqli dari tiga bentuk ashîl al-naqli yang terakhir $^{\text {iv }}$, namun materinya kontradiktif yang kontradiksinya sangat kontras dan hlm. 21 . tidak dapat dikompromikan dengan logika.(9) Menafsirkan Al-Qur'an dengan riwayat yang materinya sangat kontradiktif dan tidak dapat dikompromikan dengan bentuk ashîl alnaqli yang lebih kuat darinya. ${ }^{70}$

Adapun kekeliruan tafsir dikarenakan pemikiran yang salah (dakhil al ra'yi) didentifikasi oleh Prof. Ibrahim Khalifah dalam tujuh faktor : (1) Kesalahpahaman, kurang kompetensi sang mufassir terhadap syarat-syarat ijtihad.(2) Pendewaan terhadap logika, pengabaian terhadap makna lahir (literal) suatu kata.(3) ) Literalisme yang berlebihan dan pengabaian logika. (4)Pengungkapan makna-makna filosofis yang berlebihan.

(5) Keinginan Mufassir menonjolkan dirinya dalam kemampuan bahasa dan I'rab sehinga timbul tafsir yang dipaksakan. (6) Pengungkapan aspekaspek ilmiah yang berlebihan sehingga timbul tafsir yang aneh dan mengadaada. (7) Pengingkaran terhadap ayatayat Allah dan usaha merusak Islam. ${ }^{71}$

Mengkritisi produk tafsir yang disusun manusia yang lemah akan selalu relevan.Apalagi kalau kita sadari bahwa model pembaharuan apapun terutama yang berkaitan dengan wacana keagamaan akan selalu diawali dengan pengkritisan produk pemikiran warisan masa silam. Berbagai metode dan teknik penafsiran yang telah dikembangkan oleh para ulama terdahulu dapat dijadikan rambu dan alat yang harus digunakan secara hati-hati agar tidak tergelincir pada kekeliruan atau penyimpangan tafsir. Kekeliruan pemahaman Al-Qur'an ini berimplikasi sangat serius terhadap ajaran Islam dan bangunan budaya Islam.

${ }^{70}$ Ibrâhîm Khalîfah. al-Dakhîl. Jilid 1, hlm. 10-11.

${ }^{71}$ Ibrâhîm Khalîfah. al-Dakhîl. Jilid 1, hlm. 14-15. 


\section{E. PENUTUP}

Dalam klasifikasi tafsir AlQura'an, dijelaskan bahwa tafsir dikelompokkan kepada tiga kelompok utama, yaitu bentuk, metode dan corak tafsir. Dari segi metode muncul tafsir tahlîli analisis, tafsir ijmâli global, muqârin/ perbandingan dan maudhûi/tematik. Sedangkan dari segi bentuknya muncul tafsir bi al-ma"tsûr, tafsir bi ar-ra"y dan tafsir isyâry yang memang sudah sangat popular dalam kajian tafsir. Sedangkan terkait teknik interpretasi, dalam metodologi penelitian ilmu Tafsir terdapat banyak teknik interpretasi dalam penafsiran $\mathrm{Al}-$ Quran yaitu ; Interpretasi Tekstual, Interpretasi Linguistik, Interpretasi Sistematis, Interpretasi Sosio Historis, Interpretasi Teologis, Interpretasi Kultural, Interpretasi Logis.

Teknik interpretasi tekstual yang pada umumnya dipahami sebagai memaknai teks seperti "apa adanya teks", dipahami sesuai dengan yang tersurat tanpa melibatkan unsure luar yang elingkupi. Tafsir linguistik atau tafsir lughawi adalah tafsir yang mencoba menjelaskan makna-makna Al-Qur'an dengan menggunakan kaidah-kaidah kebahasaan. Seperti melalui interpretasi semiotik dan semantik yang meliputi etimologis, morfologis, leksikal, gramatikal dan retorikal. Sedangkan Teknik interpretasi sistemis adalah cara menyajikan pngambilan makna atau interpretasi suatu ayat dikaitkan dengan ayat-ayat lain ataupun ayat lain yang berkorelasi dalam maupun di luar surahnya atau tasir munasabah ayat. Sedangkan Interpretasi Sosio Historis mengandung pengertian penelaahan suatu objek (dalam hal ini ayat Al-Qur'an) berdasarkan keadaan, perkembngan masyarakat ketika ayat itu diturunkan dengan melakukan pendekatan secara kesejarahan (historis), atau teknik penafsiran dengan asbabun nuzul.

Metode dan teknik tersebut sangat beragam bergantung pada kecenderungan dan minat kelimuan sang penafsir. Namun Al-Qur'an bukanlah kitab bebas tafsir. Ilmu tafsir mempunyai metodologi dan kaidahkaidah yang mesti diperhatikan oleh orang yang ingin memaknai ayat-ayat Al-Qur'an. Ketidaktahuan akan kaidah tersebut menyebabkan sesorang keliru atau menyimpang dalam menghasilkan produk tafsir. Kekeliruan tafsir inilah yang dibahas dalam ilmu Dakhil. Banyak produk-produk tafsir dalam kitab-kitab klasik ditengarahi masih mengandung kekeliruan dengan berbagai sebab.

Di masa depan studi kritis atas kitab-kitab tafsir sudah semestinya dikembangkan. Meskipun literaturliteratur tafsir ditulis oleh para ulamaulama yang masyhur dan berkompeten tidaklah menutup kemungkinan studi kritis tafsir ini dilakukan. Sebab bagaimanapun karya tersebut merupakan sebuah ijtihad yang mungkin saja dapat keliru. Tafsir mempunyai peranan penting dalam ajaran Islam. Karena posisi Al-Qur'an sebagai sumber utama ajaran Islam, maka hasil tafsiran para mufassir seringkali menjadi rujukan absolut umat Islam dalam menghadapi berbagai persoalan. Wallahu A'lam.

\section{DAFTAR PUSTAKA}

Abu Nawas, Muh. Zuhri. 2015. "Teknik Interpretasi Tekstual Dan Kontekstual". Jurnal Al Asas, IAIN Palopo, Vol. III, No. 1, April.

Abu Syuhbah. Muhammad. 1408 H. Al Israiliyat wa al Maudhu'at $f i$ 
Kutubit Tafsir. Kairo, Maktabah As Sunnah.

Al Bantani Azkia Muharom. 2016. Pendekatan Dalam Tafsir: Tafsir bi al-Ma'tsûr, Tafsir bi alRa'yi, dan Tafsir bi al-Isyârah. Jurnal Hikamuna, Vol 1, No. 2.

Al -Zahabi Muhammad Husain. 2005. al-Tafsir wa al-Mufassirun Kairo: Darul Hadis.

Al Zarqani, Muhammad 'Abdul Adzim. 1980. Manahil al-Irfan fi "ulum Al Qur'an. Kairo: Matba'ah Dar Ihya al Kutub al Arabiyah.

Al-Aridh, Ali Hasan. 1992. Sejarah dan Metodologi Tafsir. terj Ahmah Akram, Jakarta, Rajawali.

Al-Farra, Abu Zakariyya Yahya ibn Ziyad ibn 'Abdullah ibn Manzur al-Dailami'. Ma'ani Al-Qur'an. Juz. III, Cet. I; Mesir: Dar alMisriyyah, t.th,

Al-Hayy, Abd Al-Farmawy. 1994. Metode Tafsir Maudhu'i. terj. Suryan A'amrah, Jakarta: PT Raja Grapindo Persada,

Al-Juwaini, Musthafa al-Shawi. Manahij fi al-Tafsir. Iskandariyah: Mansya'ah alMa'arif,

Al-Munawar, Sayyid Husin Agil. 1994. I'jaz Al-Quran dan Metodologi Tafsir. Semarang: Toha Putra.

Al-Naisaburiy, Muslim ibn Hajjaj Abu al-Hasan al-Qusyairiy. alMusnad al-Sahih al-Mukhtasar bi Naq1 al-'Adl ila Rasulillah. Bairut; Dar Fu'ad 'Abd alBaqiy, t.th, Juz III

Al-Qardawi. Yusuf. 2000. Bagaimana Berinterakasi dengan Al-
Qur'an. terj. Kathur Suhardi, Jakarta: Pustaka al-Kausar.

Al-Qurthubi Abu Abdillah. 2003. alJami' li Ahkam Al-Qur'an. Bairut Lebanon: Dar al-Kutub al-Araby, Cet. V.

Al-Suyuti, Abdurrahman ibn Abi Bakr Jalal al-Din. al-Dur al-Mansiur. Juz. VIII Bairut; Dar al-Fikr, t.th.

Al-Tabataba'I, Muhammad Husain. 1998. Al-Qur'an fi al-Islam (Mengungkap Rahasia AlQur'an). terj. A. Malik Madani dkk. Bandung: Mizan, Cet. XI

Al-Zarkasyî, Badr ad-dîn Muhammad. al-Burhân fi 'Ulûm Al-Qur'an. ed. Muhammad Abû al-Fadhl Ibrâhim.'Isâ, Kairo, al-Bâb alHalabî, cet 1, t.th.

Baidan, M. Nashruddin. 2002. Metode Penafsiran Al-Qur'an Kajian Kritis Terhadap Ayat-Ayat Yang Beredaksi Mirip. Yogyakarta: Pustaka Pelajar.

- 2011. Wawasan Baru Ilmu Tafsir, Pustaka Pelajar, Yogyakarta, Cet. II.

Halim, Abdul. 2014 Sebab-sebab Kesalahan dalam Tafsir. Jurnal Syahadah, Universitas Islam Indragiri Tembilahan, Vol 2. N0.1 April, hal 72.

Hermawan Acep. 2011. 'Ulumul Qur'an. Bandung, PT Remaja Rosdakarya.

Hitami, Munzir. 2012. Pengantar Studi Al-Qur'an: Teori dan Pendekatan. Yogyakarta: LKiS, Cet. 1. 
Ichwan. M. Nor. 2008. Studi Ilmu-Ilmu Al-Qur'an. Semarang, RaSAIL Media Group.

Khalîfah, Ibrâhîm. 1404 H. al-Dakhîl fî al-Tafsîr, Kairo: Dâr al-Bayân.

Mustaqim, Abdul. 2005. Aliran-Aliran Tafsir; Dari Periode Klasik hingga Kontemporer. Yogyakarta Kreasi Warna.

Pusat Bahasa Departemen Pendidikan dan Kebudayaan. 2002. Kamus Besar Bahasa Indonesia. edisi III, Cet. Kedua, Jakarta: Balai Pustaka.

Saeed, Abdullah. Interpreting The Qur'an: Towardsa Contemporary Approach. diterj. Lien Iffah Naf'atu Fina. 2016. Paradigma, Prinsip dan Metode Penafsiran Kontekstualis Al-Qur'an. Cet. II; Yogyakarta: Baitul Hikmah Press.

Salim, Abdul Muin. 2002. Fiqih Siyasah, Konsepsi Kekuasaan Politik Dalam Al-Qur'an. cet III; Jakarta: Raja Grafindo.
. 2011. Metodologi Penelitian Tafsir Maudhu'i. Makassar; Pustaka al-Zikra.

Shihab, M. Quraish. 2013. Kaidah Tafsir Syarat, Ketentuan, dan Aturan yang Patut Anda Ketahui dalam Memahami Ayat-ayat AlQur'an. Tangerang: Lentera Hati.

.1999. Sejarah dan Ulum Al-

Qur'an. Jakarta, Pustaka

Firdaus. 2006. Mukjizat Al-Qur'an. Bandung: Mizan Pustaka, Cet. XVI. 1992. Membumikan AlQur'an. Bandung: Mizan.

Suma, Muhammad Amin. 2013. Ulumul Qur'an. Jakarta: Rajawali Pers.

Syafrudin H. U. 2009. Paradigma Tafsir Tekstual dan Kontekstual. Cet. kedua Yogyakarta: Pustaka Pelajar.

Syurbasyi, Ahmad. 1999. Sejarah Perkembangan Tafsir Al-Qur'an al-Karim. Jakarta: Kalam Mulia, Cet. I. 